\title{
The Silent Horror Film, 1896-1922: Narrative, Style, Context
}

by

\section{Ethan Towns}

B.A. (Honours) in Film Studies, Carleton University

\author{
A thesis submitted to the Faculty of \\ Graduate Studies and Postdoctoral Affairs in partial fulfilment \\ of the requirements for the degree of \\ Master of Arts \\ in Film Studies
}

Carleton University

OTTAWA, Ontario

April 1 $1^{\text {st }}, 2020$

(C) 2020, Ethan Towns 


\begin{abstract}
This project examines early horror films before the term "horror" was popularly used. This is done by analyzing their narrative, stylistic, and national/cultural contexts. Their fascination with mysticism over horror anchors a tension between the modern and the medieval. Their treatment of monsters is informed by authorial intent, religious myth, and cultural interpretation. They are often adapted from pre-existing works and must navigate several practical and creative challenges during this process. Restoration efforts are also necessary to preserve and update these films for public screenings and home media. Several international examples will be used to illustrate these points, including Frankenstein (United States, 1910), The Golem: How He Came into the World (Germany, 1920), and Häxan (Denmark, 1922). Contemporaneous conceptions of the supernatural, as well as early cinematic devices, helped to popularize what was considered frightening - and shaped our idea of horror films as we know them today.
\end{abstract}




\section{Acknowledgements}

Many thanks are owed to the Carleton University Film Studies faculty, including Aubrey Anable (also our Colloquium mentor!), Marc Furstenau, Malini Guha, Laura Horak, Charles O’Brien, and Aboubakar Sanogo. Thanks to Tom McSorley and José Sánchez, and all the amazing contract instructors I've had the pleasure of meeting during my time at Carleton. Special thanks to my incredible supervisor, Gunnar Iversen, whose revisions, assistance, and tireless efforts are appreciated beyond measure. Thanks to my family, friends, and fellow students for their constant encouragement, especially my 2020 Grad Colloquium collaborators: Sneha Kumar, Rachel Loewen, Onoshe Nwabuikwu, and Amanda Prusila. Thanks to Alexis Luko and James Wright for their warm support, and for selecting me to present at the "200 Years of Mary Shelley’s Frankenstein" conference. Thanks also to Nancy Duff, Diane Berezowski, and Adam Milling in the Audio-Visual Resource Centre, and Alana Skwarok at the MacOdrum Library. This thesis would not have been possible without their help. 


\section{Table of Contents}

$\begin{array}{ll}\text { Abstract } & \text { i }\end{array}$

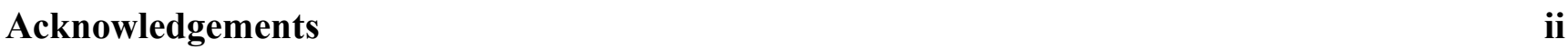

$\begin{array}{ll}\text { Introduction } & 1\end{array}$

Chapter 1 - "Excising the Repulsive: Mysticism and Psychology in Edison's Frankenstein (1910)"

Chapter 2 - "From Whence He Came: Monsters and Folklore in The Golem: How He Came into the World (1920)"

Chapter 3 - "A Satanic Sabbath: Witchcraft and the Devil in Benjamin Christensen's Häxan

$$
\text { (1922)" }
$$

Conclusion 


\section{Introduction}

Tracing the history of silent horror films can be challenging, given their obscure and multifaceted origins. The genre extends well beyond cinema itself, and everything from literature to cultural myth informs its conventions. This task is made even more difficult by the lack of consolidation around this term during the silent era. We may recognize Le manoir du diable (Georges Méliès, 1896) as the earliest horror film, given its use of associated iconography, including bats and a haunted castle. Frankenstein (J. Searle Dawley, 1910) may also be a candidate, given the notorious content of its source material, and its early development of a narrative motivated by fear. While it is an amusing question to ponder, it is almost certainly a fruitless exercise. For instance, one may argue that Le manoir du diable does not intend to scare the audience. Instead, it seeks to entertain them with the trick photography and special effects that made Méliès famous. Moreover, we may overlook international works that have not achieved the same level of notoriety, and many more have likely been lost, owing to poor preservation strategies, private collections, etc. Any number of narrative or stylistic attributes in these films might have shifted our understanding of this period in horror film history.

Film historian Kendall R. Phillips argues that the generic designate of horror in silent cinema is convenient rather than strictly correct and warns against historicizing the period as a strict pre-history. He notes that "[n]umerous historians of early cinema have warned against precisely this kind of anachronistic genre-construction and recommend treating early films not as proto-genres for later cinema but... as a unique cultural phenomenon" (6-7). He is referring to the "cinema of attractions," a term advanced by film theorist Tom Gunning suggesting films that captivate the spectator through visual effects, as opposed to narrative continuity. This adds another complication; taken as a period which extends the entire breadth of silent cinema, the silent horror film intersects with this period through such films as Le manoir du diable, with its disappearing Devil - as well as with the development of narrative. This is not to say, as Phillips would argue, that filmmakers like Méliès were 
blindly gesturing towards long-form storytelling, as if they were in a primitive stage of the genre. Rather, this quotation is used to acknowledge the complications involved in tracing a strictly causal, linear history of a genre that had not reached any semblance of maturity, commercially or aesthetically.

The period suggested in the title, 1896-1922, does not entirely cover this history. Silent horror films were still made well into the 1920s, and even beyond - the proliferation of sound production technologies was slower in some countries than others. This span is convenient for several reasons. Firstly, 1896 is the release year of Le manoir du diable; although its status is contested, and rightly so, its use of iconography and archetypes that are later associated with horror still make it a significant entry point for any discussion of the genre. Secondly, there are three case studies that best exemplify the narrative and stylistic tendencies of silent horror cinema - Frankenstein (J. Searle Dawley, 1910, USA), The Golem: How He Came into the World (Carl Boese and Paul Wegener, 1920, Germany), and Häxan (Benjamin Christensen, 1922, Sweden/Denmark). The latter does not mark the end of silent horror cinema; however, it consolidates the major thematic elements of what comes before it especially through its treatment of monsters and mysticism. I also wanted to avoid looking at three films from the same country, so I opted for an international selection. The first Frankenstein seemed forgotten in favour of its substantially more famous successor in 1931, and given its mystical slant, was a fascinating point of departure. An Expressionist example like The Golem felt necessary, but due to my historical focus, it had to be earlier, when the conventions were not as defined. Finally, I was aware of Häxan's exceptional notoriety, due to its goriness and religious overtones, and its enduring reputation in Swedish cinema from the 1920s to this day. Above all, I wanted to study films that have not received the same level of critical attention as their more culturally pervasive counterparts, like Nosferatu (F.W. Murnau, 1922) or The Cabinet of Dr. Caligari (Robert Wiene, 1920).

My analytic method involves close readings of these three films, which are all in the public domain, and thus readily available on video-sharing websites. I used the version of Frankenstein 
restored by the Library of Congress National Audio-Visual Conservation Center on YouTube, the edition of The Golem running 104 minutes on YouTube, and the Criterion Collection's Blu-ray release of Häxan, running 105 minutes. I researched the historical context of the films, both in terms of production and provenance, including preservation and restoration efforts. I also studied their narrative and stylistic elements, including what they shared and what made them different. It became apparent that monsters and mysticism were significant components of each text, which I was not aware of initially. Some primary sources addressing silent horror films and their pre-history were especially useful, including Kendall R. Phillips's A Place in Darkness: The Rhetoric of Horror in Early American Cinema, and Murray Leeder's The Modern Supernatural and the Beginnings of Cinema. However, I am indebted to many books, chapters, and articles that are relevant to different subjects that I pursue in my discussion, especially concerning monsters and mysticism.

When discussing silent horror cinema, it is impossible not to acknowledge the eminence of German Expressionism during and after this period. The Golem and The Cabinet of Dr. Caligari, two early examples, arrive the same year; Nosferatu releases around the time of Häxan; and The Phantom of the Opera (Rupert Julian, 1925) anticipates the Universal Monsters. Their heavily stylized sets, often with exaggerated features and chiaroscuro lighting, emphasize the emotional states of characters over a realistic depiction of space. While Frankenstein and Häxan do not belong to this tradition proper, their settings do have an intimate relationship with character psychology, often reflecting the morality of the individuals and institutions who occupy them. Dr. Frankenstein's laboratory is littered with occult paraphernalia, suggesting forbidden knowledge and transgression; the inquisitors' properties in Häxan juxtapose the opulence of the church with the claustrophobic terror of its prisons. And these just refer to their human characters; this is to say nothing of the monsters.

While humans can certainly exhibit monstrous behaviour, we are referring here to creatures that exist outside this category. More generally, the Oxford English Dictionary defines a monster as "any 
imaginary creature that is large, ugly, and frightening" (n. pag.), offering some common characteristics but leaving room for interpretation. Some of these films challenge these characteristics - Caligari features a hypnotized somnambulist, and the titular Phantom is simply deformed, not necessarily an imaginary entity. However, our three case studies all feature an imaginary monster that threatens the established order in some form or another, while also being created by or intimately related to that same order. Frankenstein's Monster is born of unbridled scientific curiosity and innate evil; the Golem is brought to life to protect the Jewish people, instead rampaging through the city; and the Devil in Häxan is "a nightmare, a raging demon, a seducer" (intertitles), whose malevolence is disavowed - and yet perpetuated by - the religious authorities of the time. They also disrupt an ontological order; in that they challenge easy categorizations of "human" or "monster." Film theorist Noël Carroll would argue that these monsters are "categorically interstitial" (32), and "cross the boundaries of the deep categories of a culture's conceptual scheme" (31) through their impurity. Through its spectacular creation scene, in which Dr. Frankenstein brews the Monster in a cauldron from a variety of ingredients, Frankenstein foregrounds - and makes striking use of - this philosophy of border-crossing.

These films also share a deep fascination with various forms of mysticism. In some ways, their historical settings also become "categorically interstitial," through a blending of modernity with antiquity. Out of concern for the more grotesque elements of the novel, Frankenstein was advertised in the Edison Kinetogram as having "[concentrated] its endeavours upon the mystical and psychological problems that are to be found in this weird tale" (3), as opposed to any "repulsive situations" (3) that may alienate its audience in an audio-visual medium. If we return to Frankenstein's laboratory, we can see this interest in mysticism reflected through his belongings, such as a skulls, candlesticks, and books, accentuated by his feverish elation at having "discovered the meaning of life." If we also think of the spiritual connotations of mysticism alongside the occult, this connection with the divine - or the agency over creating life - should have been enough to be blasphemous at the time. However, because 
the film is so clear in its moral distinctions - love triumphs over evil - it is possible that it was enough to denounce this transgressive side of mysticism through Frankenstein's eventual atonement.

In The Golem: How He Came into the World, mysticism is inherent to a prominent sect of Judaism called Kabbalah. The practice of shaping a golem from clay to protect the Jewish people from persecution was covered by Rabbi Judah Loew ben Bezalel in the $16^{\text {th }}$ century, whose fictional counterpart figures prominently in The Golem. Also, we can connect Rabbi Loew's ideas - as a renowned Jewish mystic - to this tradition; in fact, humanist scholar Edward Hoffman notes that “occultist Emperor Rudolph II summoned [Loew] for a private meeting in 1592, presumably to discuss such esoterica as alchemy and the Kabbalah" (95). "Presumably" does suggest a lack of certainty, but the mention of alchemy alongside mysticism does call Frankenstein to mind, given the transformation of materials involved in the Monster's creation, as well as the experiment materials. However, while that procedure was forbidden, the creation of a golem was encouraged as a defensive measure. It is only through corruption by a demonic entity, Astaroth, that Boese and Wegener's Golem becomes a threat. As a result, mysticism is not itself a negative practice, but its powers can be manipulated for the gain of evil entities. Moreover, while the film is ostensibly set in $16^{\text {th }}$-century Prague, aligning with the legend of Rabbi Loew and his involvement with a golem, there is a curiously contemporary quality to the costumes and the set design, evoking a dreamlike feeling in line with mysticism's surreal qualities.

Häxan is based off the Malleus Maleficarum, a $15^{\text {th }}$-century guide to exterminating witches for inquisitors at the time. As it took witchcraft and the Devil seriously, it evinces a deep mistrust and hatred for sorcery, and by extension, the supernatural qualities of mysticism. By contrast, the film seeks to understand how this hysteria can manifest and does not condemn mystical practice with the same conviction and fervour. In fact, Häxan studies mysticism with an almost academic interest, especially in its opening section. Aided in part by an offscreen lecturer, who points to important details with a stick, a series of woodcarvings and paintings - narrated by intertitles - describe, among other things, 
celestial bodies and cultural ideas of Hell. Cultural critics Richard Baxstrom and Todd Meyers argue that "Christensen is operating in a firmly rationalist mode here, linking these monsters [in Hell] to "naïve notions about the mystery of the universe" held by ancient people" (36); essentially, they are arguing that only primitive cultures and belief systems would lend credibility to their existence. They are more interested in the behaviour of those who do believe in the occult, or manipulate this belief to suit their needs, as the inquisitors arguably do later in the film. This is also intimately tied to the concept of superstition, including the evaluative criteria used to determine if one is a witch, or possessed by the Devil, among other things.

In some way, mysticism is linked to the monsters of these films. Even their titles demonstrate this connection; Frankenstein is the doctor that cooks the Monster into being, The Golem details precisely "how he came into the world" through a magic word, and Häxan translated from the Swedish means "the witch," made more explicit in the subtitle "Witchcraft Through the Ages." While the latter has a more nuanced understanding of its apparent monster, indeed questioning who the real monsters really are, it still embraces sensational terror and grotesque imagery - as evidenced by the bacchanalian Sabbath scene in the forest. It is easy to see the appeal of monsters in horror, even before they were recognized as such; Noël Carroll even argues that it is necessary for horror films to have monsters. The appeal of mysticism is less uniform and obvious; Frankenstein's marketing used it as an alternative to "repulsive situations," it is a crucial element of the Golem's cultural mythology, and it is connected to occult practices that have traditionally stoked hysteria, as in Häxan. The easy answer would be that it is somehow inherently connected to the experience of fear, which would relate it to the generic mandate of horror - but it is not. However, it is a common preoccupation across these three prominent international films and is related in important ways to the more obvious presence of monsters.

In terms of speech, it is erroneous to say that silent films had no talking, just that synchronized sound was not yet standardized. Intertitles served this function, delivering dialogue and expository 
narration. However, Frankenstein - having arrived earlier than these other films - did not have any discernible lines; the actors were clearly speaking, but even the intertitles were reserved for story details. Film scholar Rick Altman argues that "[i]nterest in dialogue spawned increasing fascination with faces - not just moving lips but also the facial expressions that give dialogue its depth" (173), or the ability to emote over strict synchronization. He goes on to suggest that "greater use of close-ups was also influenced by increasing narrative complexity and star-studded marketing" (173), intertwining storytelling and style with the film's commercial expectations.

From the standpoint of silent horror cinema, close-ups also allow the audience to see more defined expressions of terror on actors' faces. In Frankenstein, staging was still theatrical, and the camera was stationary - spatial and temporal continuity reigned supreme. While Augustus Phillips' acting is gesturally expressive, and we can discern his looks of shock, due to these formal norms - and deteriorating prints - these reactions are not as clear as we maybe would like them to be. In Häxan, these looks of horror are clear and highlighted. One scene shows a monk studiously poring over a holy text at an altar; his back is to the camera, and behind the altar is a black abyss. Suddenly, the Devil appears behind the altar, startling the monk, whose wide-eyed look of horror is shown in close-up. Here, we are fascinated by how facial expressions express emotion alone. As Altman says, this is enhanced by narrative film, and we could add the development of genre as well - filmmakers take advantage of formal strategies to best communicate the fear of the characters.

Music is another crucial element of silent horror cinema. This could mean orchestral accompaniment in the theatres themselves, musical cue sheets that provide notation per scene, or original scores produced by independent organizations long after the film is released. Some musicians could improvise their own content, but some companies preferred to publish their own recommendations. This could indicate the tempo at which the music should be played (andante, moderato, agitato); music from operas and plays (Annie Laurie, Der Freischütz); and the narrative 
function it should serve ("dramatic music"). These examples are taken from an existing cue sheet for Frankenstein, which are invaluable to scholars of film music as indications for how companies sought to organize this material. It also accentuates the intertextual and transmedia nature of early film music, in that the dramatic significance of one work/medium directly influences that of another. It is possible that this strategy was borrowed from theatrical adaptations of Frankenstein; for instance, playwright Henry Milner - who wrote a stage adaptation in 1826 - gave explicit instructions for music during crucial scenes of horror. As for original film scores, it was not until five years later that they became popular on their own, like Joseph Carl Breil's “The Perfect Song," from The Birth of a Nation (D.W. Griffith, 1915). In the 1920s, it is easier to find credited composers for contemporaneous scores - Hans Landsberger is credited for The Golem: How He Came into the World, and Launy Grøndahl's original work is present in Häxan alongside significant contributions from Ludwig van Beethoven.

Today, independent groups will perform their own scores alongside screenings of silent films. For example, the VOD Silent Film Harmonic "takes its inspiration from how many silent movies were originally presented - taking themes and using them as the basis for improvisation" (n. pag.), even adding spontaneity to their performance strategies. International composers and musicians will also write original scores for home media releases, special festival screenings, and other restorations of these films, often with significant creative liberty. Giorgio Moroder's electronic score and curated soundtrack for Metropolis (Fritz Lang, 1927) is often cited as a famous - or rather, infamous example. Various editions of The Golem: How He Came into the World have soundtracks by Karl-Ernst Sasse and Aljoscha Zimmermann, with versions of Häxan being scored by Daniel Humair, Art Zoyd, and Matti Bye, among others. Renowned silent film composer Donald Sosin has also produced new music for the Library of Congress's 2018 restoration of Frankenstein. For silent horror cinema, and silent cinema writ large, there is more opportunity for artists today to showcase their own interpretations of the musical soundscape, whether through fidelity to contemporaneous cue sheets, 
completely original scoring practices, or a combination of both.

My three case studies are also adapted from previous material. This is quite common for silent horror cinema - other prominent films include Dr. Jekyll and Mr. Hyde (John S. Robertson, 1920), and The Man Who Laughs (Paul Leni, 1928). For our case studies, Frankenstein is based on Mary Shelley's Gothic horror novel of the same name; The Golem (and its related films) are inspired by Gustav Meyrink's mystical novel of the same name; and Häxan takes its subject matter from the Malleus Maleficarum, written by prominent $15^{\text {th }}$-century Catholic Heinrich Kramer. All take a loose approach to their source material, to varying degrees. For instance, the first intertitle we see in Frankenstein characterizes the film as “[b]eing a liberal adaptation of Mary Shelley's novel," acknowledging the need for change. Because Frankenstein is a "one-reeler" film, running around 14 minutes, the filmmakers had to condense the material in order to fit this standard length of time. Instead of depicting the many sub-plots, location shifts, and characters of the novel, the film focuses on Frankenstein's moral duality, and love conquering the evil impulses that gave birth to the Monster.

The Golem: How He Came into the World is related in name only to Meyrink's work. Although both film and novel are set in Prague, where Rabbi Loew's golem is said to have been created, they take place in different time periods. The former is ostensibly set in the $16^{\text {th }}$-century - despite some anachronistic elements - and the latter is set around the end of the $19^{\text {th }}$-century, with some dreamlike time travelling involved. The film also closely hews to the original legend, whereas the novel tells the story of an unnamed narrator who inhabits the consciousness of Athanasius Pernath, a Prague jeweler. In different ways, these works also deal with the persecution that Jewish people face, whether it is by imperial decree or societal treatment - Meyrink's own descriptors are also problematic. Häxan's relationship with the Malleus Maleficarum is also one of superficial inspiration; however, despite its outlandish claims, the Maleficarum did purport to be a non-fictional guide to hunting witches. Christensen uses it as a tool for his thesis, and maybe even an excuse for sensationalism. By depicting 
the behaviour the Maleficarum endorses, he is showing how it led to the mass hysteria which caused the death of many innocent people, but he is undoubtedly aware of its morbid spectacle as well. As Ben Rothwell notes in the Introduction to the 1948 edition, "there is no question that the psychological effect [of hysteria] was incalculable, and harmful to the highest degree" (vii).

Literary scholar Linda Hutcheon argues that "there are significant differences between being shown a story and being told a story" (xvii), and this has important implications for silent horror cinema. When we consider film as an audio-visual medium, we are likely thinking of the moving image, speech, sound effects, and music, the latter three of which are identified by film music historians James Buhler and David Neumeyer as the key components of a film's soundscape. However, with silent films we are being shown a story - through the moving images - but also being told a story, through the literary qualities of the intertitles. As has been mentioned, these intertitles serve to narrate the film's events, but also to communicate dialogue, with the latter becoming more prevalent as certain formal techniques - ex. close-ups - became more popular. Due to the limited space on screen as well, both within the frame and for the duration of the film, each sentence should only contain information that is crucial to the narrative. This often forces filmmakers to abbreviate established story arcs, sometimes with amusing results. For instance, the first intertitle for Frankenstein reads "Frankenstein leaves for college," showing him depart from his family house thereafter. The next slide suddenly says, "Two years later, Frankenstein has discovered the meaning of life," showing his harried work in his college(?) laboratory. For such an existential revelation, that is an exceptionally impressive timeframe. Most of the writing on silent horror consists of filmographies, encyclopedias, and chapters in books on the horror film. There is, of course, the occasional treasure that focuses exclusively on the period this thesis covers, including Kendall R. Phillips's A Place of Darkness: The Rhetoric of Horror in Early American Cinema. As with this project, he focuses on the narrative, stylistic, and contextual elements of horror films before they became known as such. His stated goal is to "trace a line through 
the complex conditions of cinematic and cultural history and to focus on the ways that horrific elements were framed and made meaningful" (186). My objective is to discover which of these horrific elements are most prevalent, how they manifest themselves differently, but also how they have similar preoccupations that are significant in a pre-horror context. This especially revolves around mysticism, which may be connected to horror but is more readily associated with alchemy, the occult and spirituality. There is also a timelessness to Frankenstein, The Golem: How He Came into the World, and Häxan, which blends different historical periods - especially the modern and the antiquated - into something entirely new, suggesting a tension between backward thinking and scientific advances.

In chapter 1, I will focus on Frankenstein and its emphasis on mysticism and psychology in its narrative. I will also discuss its history as a lost film, including its discovery in a private collection and restoration by the Library of Congress. Its status as an adapted work will also be touched on, including the necessary cuts to fulfill its 13-minute running time. I will further highlight the use of mysticism through the character of Dr. Frankenstein and his role as a modern-day alchemist, as well as in the film's contemporary marketing materials. In chapter 2, I will look at similar contexts for The Golem: How He Came into the World, including different restorations - in several formats - throughout the years, and its liberal adaptation of its source material. The film's use of Kabbalist mythology and Kabbalah's mystical connotations will also be crucial in connecting the film to Frankenstein, as will Noël Carroll's interpretation of the monster figure. In chapter 3, I will talk about Häxan, again addressing its provenance through preservation and restoration, but I will forego evaluating its closer connections to the Malleus Maleficarum. More than anything, the film feels like an addendum to the general project of the Maleficarum, rather than a retelling of the events therein. I will use this space to focus on its unique episodic structure and its defiance of traditional genre norms, especially documentary and drama. Finally, I will address the film's presentation of the Devil and witchcraft, their relationship with reality, and their connection with the extreme stigmatization of mental illness that 
endures into the present. The conclusion will touch on any outstanding similarities and differences between the films, as well as the major thematic preoccupations of the silent horror cinema. 


\section{Chapter One:}

\section{Excising the Repulsive:}

\section{Mysticism and Psychology in Edison's Frankenstein (1910)}

Edison Studios' Frankenstein is a staple of American silent horror in the 1910s, owing partly to the immense popularity of its source novel and the contemporaneous fprevalence of stage adaptations. Unfortunately, having been lost for decades, it also illustrates the difficulties in tracing a comprehensive history of the genre. As the first film adaptation of Mary Shelley's seminal novel, it is instructive to look at the practical and moral decisions that influence that process. What should be included? What should be omitted? What are the motivations behind these choices, and how should they be depicted onscreen? Edison's Frankenstein prefers to emphasize the mystical and psychological

qualities of the novel, particularly in terms of the Monster's creation, as well as his relationship with his rueful creator. Despite this frightful subject matter, the Edison Kinetogram catalogue stressed that they "carefully tried to eliminate all actual repulsive situations" (3) - contrary to the centrality of disgust in horror. Its provenance as a lost film also encourages the use of private collections, film archives, and restoration efforts to continue the work of film preservation, through which we may continue to find silent (horror) films. In this chapter, I will address the adaptation of the novel, the alchemic qualities of the Monster's creation, the psychological elements of the film, and its preservation process. This will allow me to present a full overview of the film, from its source material to subsequent restorations, as well as its treatment of monsters and mysticism. These two focuses are not only crucial to the film's marketing, but also to its relationship with the thematic concerns of silent horror cinema more broadly.

Mary Shelley's Frankenstein; or, the Modern Prometheus is a classic of Gothic literature, originally published in 1818. The title also refers to the Greek mythological figure Prometheus, a Titan who stole fire from the gods and was thenceforth associated with transgressive forms of knowledge. Victor Frankenstein is much the same, in that he aspires after the power of God to create life. The novel 
was originally conceived as an entry into a contest that Shelley, her husband Percy, and friend Lord Byron held while staying in Geneva on a dark and stormy night. At a loss, she conceived of the story later: a medical student unwittingly creates an intelligent Monster, who feels alienated by the outright rejection of his father figure. Part epistolary novel, part first-person narration, the story is told through a captain's letters, who crosses paths with Frankenstein; Frankenstein himself, for the majority of the novel; and the Monster, who relates his linguistic and emotional development by observing people. This exposes the reader to the thoughts and feelings of both protagonist and antagonist and allows us to experience the world through the Monster's subjective point-of-view. Adapting this narrative into one reel would have been a daunting challenge, and the use of cinematography and editing to express similar ideas to Shelley is a showcase for the stylistic development of silent horror cinema.

Written and directed by J. Searle Dawley, and produced by the Edison Manufacturing Company, the film concerns the infamous experiments of Dr. Frankenstein (Augustus Phillips). He wants to discover the "meaning of life" at medical college, which he remarkably achieves in two years. Rather than sewing together a patchwork corpse and using lightning to revive it, as in the novel, Frankenstein gives life to his Monster (Charles Ogle) in a smouldering cauldron. This has been called "probably the most weird, mystifying, and fascinating scene ever shown on a film” (Edison Kinetogram), and remains a stunning innovation in special effects. Frankenstein is aghast at the abhorrent appearance of the creature, and faints in shock. After recovering from his ordeal at home with the help of his family, including his fiancée, Elizabeth (Mary Fuller), it is determined that "Frankenstein had allowed his normal mind to be overcome by evil and unnatural thoughts." His uninhibited curiosity resulted not in an achievement of science, but in an abomination of alchemy, offensive in both outward form and as a manifestation of Frankenstein's sins. Instead of being portrayed as a sympathetic, articulate creature, the Monster appears as an extension of Frankenstein's worst impulses: all tattered rags, gangly limbs, and contorted facial expressions. Ultimately, "the creation of an evil mind is overcome by love and 
disappears." Here, pure emotion is enough - especially as validated by heterosexual matrimony - to both exorcise a literal demon, and those of Frankenstein's mind.

\section{"It's Alive!": Finding and Restoring Frankenstein}

Like many silent films, Frankenstein was considered lost for six decades. Poor preservation methods, privately maintained collections, and the destruction of prints considered unimportant and dangerous are just a few factors that have contributed to this dearth of availability. It represents a lack of primary sources for film scholarship, but even surviving films become the object of debate. As film archivist Paolo Cherchi Usai notes, "[m]any attempts have been made in the preservation of silent films to seek a compromise between integration, conservation and the pleasure of viewing" (272). In other words, how can a balance be struck between maintaining their original material context, while also making them available for reconstruction and exhibition? As an example of a film that was lost and found, Frankenstein represents an interesting example in this sense, especially as we have retroactively assigned it the label of "horror" due to its literary legacy.

Alois F. Dettlaff, Sr., was a film collector from Milwaukee who had announced his ownership of a copy of Frankenstein after the American Film Institute had included the film on a 1980 list of "culturally and historically significant lost films." "The print had originally belonged to his wife's grandmother who used to screen the film and other silent shorts as part of a stage show" (FilmBuffOnline, n. pag.) which not only illustrates the typified composition of film programming in the era, but also the relationship that theatre shares with the moving image - as well as horror, more specifically. As Rick Altman observes, "[d]aily language assimilated films to several different media...they seemed to belong to the realm of theater" (124-125), made even more apparent by decorative features such as prosceniums. Silent horror films have also been associated with Grand Guignol, a theatrical tradition that featured gory violence and macabre imagery, but "cinema could only hint at what the Grand Guignol presented with graphic specificity...[due] to the twin exigencies of 
social norms and censorship" (Dixon, 24).

In the 1980s, when the existence of Frankenstein - and its gradual exhibition - became known, the landscape of cinema had shifted dramatically. Dettlaff had previously permitted its excerpted use in a BBC documentary, but after having received no compensation or acknowledgement, he began to mistrust the intentions of interested parties. Eventually, he held public screenings of Frankenstein in Milwaukee and Jersey City, as part of retrospectives on Frankenstein films.

In any case, this acted as a prelude to subsequent restoration efforts, including those by the Library of Congress and the University of Geneva, demonstrating the enduring international, cultural, and academic investment in saving silent films. After a nitrate print was acquired by the Library as part of the Dettlaff collection, a $2 \mathrm{~K}$ scan was performed before photochemical preservation efforts - and digital restoration - could be done. In 2017, one version was published by the Library of Congress National Audio-Visual Conservation Center as a digital MPEG-4 video file, tinted for effect from the original black-and-white. Notably, the list of genres the Library includes on the film's online profile include: Mad scientist, Monster, Horror, Silent, Short, and Fiction, while a list of subjects include: Experiments, Good and Evil, and Science. While these may be convenient labels in order to sort their collection, it foregrounds the methods we use to categorize films according to their narrative and stylistic elements. "Silent," "Short," and "Fiction" are general enough; the keywords "Mad scientist," "Monster," and "Horror," however, suggest the building blocks of a horror narrative that Noël Carroll would call the "overreacher plot."

According to Carroll's formulation, "the overreacher plot is concerned with forbidden knowledge - of either the scientific or magical sort" (118). He goes to say that it "criticizes science's will to knowledge" (118), through the punishment of the individual whose hubris compels the transgressive actions. Here, the arrogant mad scientist creates the Monster; in Edison's version, "the evil in Frankenstein's mind" is separate from his conscious efforts, but nevertheless qualifies him for 
this archetype. As for the "Mad Scientist" subject, he is clearly conducting scientific experiments, but as we have addressed, this is intertwined with an interest in alchemy and natural philosophy. The inclusion of "Good and Evil," is especially telling for this version of Frankenstein. The prideful evil overreaching creates the Monster, and the good emotion of love, manifested through Frankenstein's feelings for his fiancée, is enough to banish the Monster from our world. As a result, these simple keywords indicate a complex interplay between the generic and moralistic conventions that make silent horror cinema - and Frankenstein specifically - so singular.

Almost simultaneously, the film was restored by Le comité du Ciné-club universitaire at l'Université du Genève, the city where Lord Byron and Mary Shelley resided, as did the Frankenstein family in the novel. Graphic designer Julien Dumoulin handled the image work, listing his duties as "restoration, retouching, [and] calibration," which were sponsored by les Activités culturelles de l'Université du Genève. Swiss musician Nicolas Hafner composed an original soundtrack upon request; according to the University, he "imagined an original sound...and interpreted it on the magnificent...[Wurlitzer] organ of Claparède College" (translated from French). This demonstrates the original scoring work that must be done to supplant live musical elements, or soundtracks that have deteriorated beyond repair. The restored version was then screened by the Ciné-club as part of a retrospective on Mary Shelley, much like Dettlaff loaning his print to festivals oriented around similar themes.

\section{Adapting Frankenstein: From Novel to Silent Cinema}

Gothic literature provided plenty of material for silent cinema. Moreover, with Gothic works having historically explored the nature of fear and dread, its connection to what we now recognize as filmed horror makes more sense, despite efforts to censor controversial material. Karen E. Laird argues that "[ $\mathrm{t}]$ he morality of cinema debate thus sparked Edison's embrace of adaptation, but also put pressure on the studio to bowdlerize literary source texts in order to appease the moralists" (116), 
which suggests that the written word was not instantly safe. This speaks to the familiarity of literary works, but also the myriad attempts to remove any sensitive content - from extramarital relationships to criminal acts - in a popular audio-visual medium.

The original novel is filled with violent content, related through the perspective of Frankenstein and the Monster. However, the Monster's appreciation of nature, senses, and good manners questions the idea of innate evil, as they are his first instincts over murderous rage. Cruelty or horror is inflicted on him because of his hideous and threatening appearance; this is only exacerbated by self-reflection, as "[i]ncrease of knowledge only discovered to me what a wretched outcast I was" (Shelley, 99). After approaching a home out of the wilderness, whose inhabitants he had been observing, the Monster is driven out by the blind patriarch's son, after speaking with the former without fear. After burning down their home and "[i]nflamed by pain, [the Monster] vowed eternal hatred and vengeance on all mankind" (108), representing a turning point in his malicious intent. He murders Frankenstein's tenyear old brother, William; his best friend, Henry, and his new wife, Elizabeth, feeling "triumph" (109) instead of guilt. He is entirely motivated by the sufferings of his creator, wishing to make him feel as miserable as he has for merely existing in the world.

The film's version of the Monster is framed as an extension of Frankenstein's "evil thoughts" that can be overcome by the power of love, rather than an autonomous being capable of intelligent thought. While Shelley hints at this deeper connection through Frankenstein's guilt - "I felt as if I had committed some great crime, the consciousness of which haunted me" (126, italics mine) - the codes of narrative cinema had not consolidated an equivalent sign system for character psychology. Intertitles say that "Instead of a perfect human being, the evil in Frankenstein's mind creates a monster," and “...Frankenstein's better nature asserting itself,” but there is no dialogue illustrating Frankenstein's thoughts, or any acts of violence that would provoke revenge. Where "a person [may be] unable to integrate some immoral or unacceptable behaviours within the self" (Forcen, 16), reflecting "the 
duality of good and evil, which reflects the double morality of the Victorian era" (17), Frankenstein is able to "overcome" his transgressions, if not totally eradicate the evil.

More broadly, novelist John North notes that "[w]riting a screenplay based on a great novel is foremost a labor of simplification" (Hutcheon, 1). Through author Louis Begley, North suggests that this is not a matter of simply pruning the plot, but also "the intellectual content" (1), saying that an image-based medium is less complex than a word-based medium. This is highly provocative and goes against the innumerable images and sounds that have been able to express anything and everything throughout film history. However, it is important to note these opinions, as it forces us to consider how certain ideas are translated - and abridged - from page to screen. This is relevant when discussing Edison's Frankenstein, which only ran fourteen minutes. This runtime is not an inherent hindrance; Linda Hutcheon, who originally quotes North in A Theory of Adaptation, observes that "adapters actualize or concretize ideas; they make simplifying selections, but also amplify and extrapolate; they make analogies; they critique or show their respect, and so on" (3).

It is easy to see how the makers of Frankenstein had to make "simplifying selections," but they also "concretize ideas," namely Frankenstein's moral dilemmas. The resolution to these problems in the novel is very different, involving murder, death, and implied suicide. In the film, love triumphs over evil personified, but basic plot elements and character qualities are still respected. For example, the Monster is still explicitly jealous towards Frankenstein for having a mate. In the novel, this results in a quest to get one made for him, an idea that is developed in James Whale's Bride of Frankenstein (1935). It could also be argued that the mystical and psychological themes of the novel are amplified and extrapolated. This is done by changing the context of the Monster's creation, as well as the use of certain compositions and mise-en-scène to express ideas about the interior states of the characters. Instead of being struck by lightning in Frankenstein's laboratory, the Monster is an alchemic concoction that is cooked in a cauldron. While both their thoughts are privileged throughout the novel, the use of 
mirrors and dream-like compositions frame the Monster as an extension - or double - of Frankenstein. While there is no significant segment involving a mirror in the novel, the Monster does see his reflection in a pond, and remarks that "I became fully convinced that I was in reality the monster that I am...filled with the bitterest sensations of despondence and mortification" (190). This, and stage adaptations that used actual mirrors, would have been the inspiration for the equivalent scene in the film. As a result, a familiar Gothic novel - and its contemporaneous stage adaptations - are mined for crucial scenes and characters and re-interpreted to reflect the moralistic concerns of the era, using what Hutcheon describes as "the comfort of ritual combined with the piquancy of surprise" (4).

The $19^{\text {th }}$-century stage adaptations were also influential in terms of the cultural conception of the Frankenstein myth. Far from being inconsequential interpretations of the story, these first performances of the story shaped subsequent editions of the novel. For instance, Mary Shelley incorporated dialogue from stage plays of Frankenstein in the 1831 edition, which also featured illustrations that are clearly borrowed in the 1910 film. This includes a scene where the Monster approaches Dr. Frankenstein menacingly, with the latter's look of horror featured prominently, along with a row of skulls and a human skeleton close by. This suggests a closer relationship between a variety of different media, now including theatre, than was previously expected; this also relates to silent cinema's preoccupation with the macabre, as this mordant imagery is clearly also present in the 1831 edition of the novel, and likely the play as well. Until the Edison film came along, the plays were probably the version of the Frankenstein story that audiences were most familiar with; as cultural historian Steven Earl Forry observes, it is only " $[\mathrm{w}]$ ith the advent of the twentieth century that moving pictures increasingly encroached upon the heretofore unchallenged domination of the theatre" (79).

\section{Man-Made Monster: The Mad Scientist as Alchemist}

Shelley's Frankenstein seeks to differentiate the modern sciences from natural philosophy, which Frankenstein gravitates toward at university. The German city of Ingolstadt "housed a medical 
school, and was a well-known center of progressive learning...[i]ts advocacy of free thinking and radical politics got it outlawed in 1785" (Wolfson, 25). This association of innovative research and transgressive ideology with Frankenstein's own interests sets the stage for his experiments. After finding one Professor Krempe "repulsive" (Shelley, 28) for dismissing natural philosophy as antiquated, Frankenstein attends a chemistry lecture by Professor Waldman, and becomes enraptured by its subject matter. Waldman says that ancient philosophers of chemistry "[penetrated] into the recesses of nature" (29), and gives miraculous descriptions of their powers, in contrast to his "cursory view of the present state of the science" (29). The term "recesses" suggests a forbidden or secluded space, accessible only to those who are daring enough to search for it. As a result, the quest for knowledge is not associated with modernity here, but an illicit curiosity.

In Edison's film, the first sequence we see is Frankenstein leaving for college. In a static long shot - customary for the time - Frankenstein bids farewell to his parents, dons his top hat, and exits the parlour from the left. Rather humorously, but given the demands of time, the next intertitles relate that "Two years later, Frankenstein has discovered the secret of life," showing him gesturing theatrically in celebration and writing his discoveries down. His study chamber is packed with skulls, books, and what appears to be a human head, offering a curious blend of the macabre and academic. This film omits the attitudes he develops about his professors, but this set design suggests a ghastly devotion to his work that transcends accepted norms. In a letter to his fiancée, Elizabeth - shown in close-up for the viewer he states his mission to "create into life the most perfect human being that the world has yet known." This mission questions the traditional logic of divine creation, as Frankenstein is implicitly challenging God's faultlessness and supremacy. In the novel, this is more explicit: Frankenstein brags that "[a] new species would bless me as its creator and source" (Shelley, 34), going beyond scientific curiosity by using religious language and positioning himself as a deity. The Monster furthers this by arguing that "I am thy creature: I ought to be thy Adam, but I am rather the fallen angel”(73). 
Frankenstein's interests, especially in the novel, are certainly more aligned with alchemy than the modern sciences. Defined by Merriam-Webster as "the medieval chemical science and speculative philosophy whose aims were the transmutation of base metals into gold, the discovery of a universal cure for diseases, and the discovery of a means for infinitely prolonging life" (n. pag), its combination of markedly different disciplines and objectives hew closely to Frankenstein's work. He is fascinated by the intersection of chemistry and natural philosophy, combining disparate elements to make something new, and "the secrets of life," which could create "the perfect human being."

In the film, these unorthodox experiments are affected by moral depravity. Instead of the flawless specimen he wanted, "the evil in Frankenstein's mind creates a monster." It is difficult to say whether the procedure itself is condemned as wicked, but Frankenstein's worst impulses have clearly corrupted his conscious efforts to create something perfect. Likely, it is to set up the climactic conflict at the end of the film, in which Frankenstein's love for his fiancée is powerful enough to literally banish the manifestation of his sinful desires from the world. This classic triumph of good over evil is nowhere to be seen at the end of the novel. While "a high destiny seemed to bear [Frankenstein] on" (Shelley, 167) towards killing the creature after it murders Elizabeth, he ultimately fails in his efforts. The Monster prepares to kill himself at "the extremity of the globe" (178), after recognizing that "[e]vil thenceforth became my good" (176), which is "Satan's principle" (176, from Paradise Lost). This is a highly defeatist version of events, in which both characters succumb to their sins, and find no escape or definite absolution.

The actual scene of the Monster's creation in Edison's Frankenstein features impressive special effects for its time. After mixing ingredients in a bowl and dashing them into an enormous cauldron, sealed behind doors as the process unfolds, Frankenstein excitedly observes the birth of the creature. Like other silent horror films, what we now understand as key iconography plays a role in this scene. There is a skeleton to the left of the frame throughout the entire sequence; while this is a common 
feature of laboratories and science classrooms, its association with early "trick" films demonstrates its relationship with silent cinema. As film scholar Murray Leeder notes, "[e]ven a cursory survey of early cinema finds that filmmakers were positively fascinated by skeletons: they appear frequently in trick films by Walter R. Booth, Edwin S. Porter, Émile Cohl, Segundo de Chomón and others, as well as [Georges] Méliès and [George Albert] Smith" (137). The Monster starts out as a misshapen blob, then a skeletal shell, gradually gaining flesh to become man-like in the end, highlighting the macabre attraction of such imagery alongside the pioneering special effects.

Méliès's work is perhaps most relevant in this regard. His 1896 film, Le manoir du diable, is frequently cited as the first horror film; this is debatable, given its emphasis on fantastic effects as opposed to frightening or disgusting elements. Two soldiers enter a castle that is occupied by evil entities and witness the appearance and disappearance of a skeleton in a chair, which turns into a bat and then, the Devil. While this is a showcase for Méliès's special effects, the association of skeletons with macabre imagery and black magic carry into Frankenstein's own cautionary tale. It is also worth noting that a cauldron also features prominently in Le manoir du diable; after the Devil produces it out of thin air, he uses it to create a woman (played by Méliès's frequent collaborator and wife, Jehanne D'Alcy). She is later brought before the soldier then turned into a "withered old crone," before finally appearing as four ghostly apparitions. As with Frankenstein, the cauldron is initially used to miraculously produce a human being. Here, the process is corrupted through the personification of evil, rather than unconscious evil. 


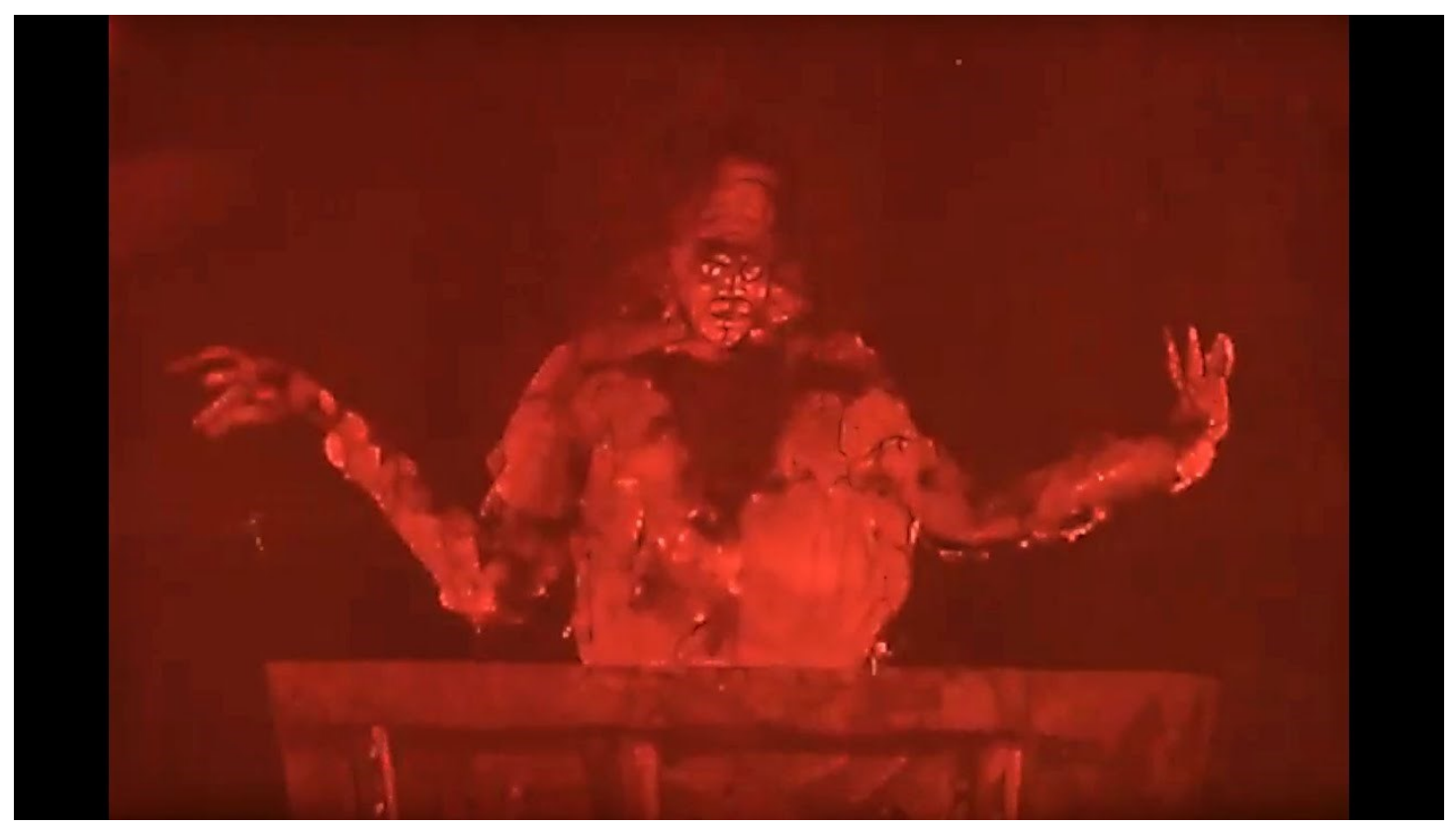

This use of skeletons, ghosts, monsters, and devilry is representative of silent horror's fascination with these figures, as well as its connection with antecedent forms of entertainment. On the other hand, technology is strikingly sparse, elevating the occultist nature of Frankenstein's research over the scientific experiments of the novel. With regards to spectral and gruesome images, "[e]arly cinema's place on a lineage of haunted and haunting media is at least as important as its newness" (Leeder, 3). From X-ray exhibitions to Grand Guignol theatre, these visuals were assisted by pioneering special effects in a variety of contexts. In a way, the cauldron scene in Frankenstein acts as a successor to these visuals, in service of a macabre spectacle. The Monster comes to life in a fiery, Hadean scene, all gangly limbs and smouldering skin against a black background. Even today, one marvels at how this was achieved. In fact, a dummy was set on fire and manipulated through puppetry, with the footage being played in reverse to suggest the formation of a creature, rather than its destruction.

\section{A Reflection in the Mirror: The Psychology of Frankenstein}

As stated in the Edison Kinetogram, a film news periodical published by Thomas A. Edison, Inc., Frankenstein was adapted to emphasize the "mystical and psychological elements" instead of "overtly horrific content," to appease any moral concerns. In the March $12^{\text {th }}, 1910$ issue of trade 
magazine Moving Picture World, this position is reinforced: "the dissolution [of the monster] through the force of true love is most vividly presented with the repulsive situations eliminated" (392). This is reiterated in Edison publicity material for the same issue, which states that " $[\mathrm{t}]$ he actually repulsive situations in the original version have been carefully eliminated in its visualized form, so that there is no possibility of its shocking any portion of an audience" (428, italics mine).

Psychological horror is a prominent sub-genre that is almost as old as horror cinema itself, in which interior states are visualized and utilized in a narrative context to frighten viewers. It is puzzling that "psychological elements" are at odds with "overtly horrific content," the latter of which is later associated with film as "visualized form." It is reasonable to conclude that as long as the horrific content is concealed or implicit, it can technically be allowed in the film.

Simplistically, psychology deals with the mind in a scientific context. It also asks how our behaviours are conditioned by interior and exterior forces. Much of this is unable to be visualized; while our emotional states are partially reflected in the way we act, mental diseases are often categorized as invisible illnesses by society. Until the narrative and aesthetic codes of psychological horror were consolidated, this linking of psychological elements to the invisible - i.e. not "overt" might have motivated this approach by Edison Studios.

From a stylistic perspective, there is a self-reflexive element to Frankenstein watching the Monster's creation. Elizabeth Young argues that the viewing hole he uses "simultaneously symbolizes the lens of a camera and the hole through which such images, after the development of projection technology in the 1910s, were projected onto a screen" (165), connecting Frankenstein's voyeurism with contemporary cinematic apparatuses of production and exhibition. There is a psychological aspect to this; Young observes that the viewing hole is also "a two-way aperture into Frankenstein - a window into his psyche as well as an orifice through which he himself peers" (166). This is supported by the conflict between his conscious and unconscious desires, but more explicitly by the moralistic conflict 
between good and evil in his mind that the film revolves around. The intertitles make it explicit, but through these shots, it is as if we actually see the evil in Frankenstein's mind - formally represented in the hellish cauldron inferno - cook the Monster into being. Of course, Frankenstein is also positioned as the ideal spectator, awestruck by the spectacle of the Monster's creation, which was emphasized as one of the primary attractions of the film.

Using mirrors, Edison's Frankenstein deals with the fractured self by framing Frankenstein and the Monster as one and the same. As I have suggested, the Monster is an extension of Frankenstein's worst impulses; using the Freudian model, his "evil thoughts" represent his id - the locus of immediate gratification and instinct. In Shelley's novel, Frankenstein narrates that "my father had taken the greatest precautions that my mind should be impressed with no supernatural horrors" (32), or unnatural curiosities about life and death. Frankenstein further notes that "[a] human being in perfection ought always to preserve a calm and peaceful mind, and never...allow passion or a transitory desire to disturb his tranquillity" (36). While this could be seen as an overestimation of agency over one's mental health, it also condemns Frankenstein's "transitory desires" surrounding the supernatural, which haunt his thoughts for the rest of the novel.

After the creation scene, the Monster emerges from the experiment room and stalks Frankenstein through his apartment. After leaving the room, and entering his bedroom screen right, Frankenstein falls onto his bed, and the Monster emerges from behind black drapes. This is likely a visual quote of The Nightmare, a Romantic painting by Henry Füseli, given the dark background, the dreamlike quality of the framing, and the Monster's obsession with his creator. After he is frightened further, Frankenstein leaves for his bourgeois home, and the comfort of his fiancée, Elizabeth.

This blissful domesticity does not last long. As the intertitles narrate, "[h]aunting his creator and jealous of his sweetheart, for the first time the $[\mathrm{M}]$ onster sees himself." The Monster is inextricably tied to Frankenstein, as if his shadow - he covets what his creator does, desiring the comfortable life that he 
left him for. As Frankenstein is reading in a parlour, situated left-of-frame in a medium long shot, the Monster enters offscreen. Here, we see his entrance through a floor-standing mirror right-of-frame. As he harasses his creator, their interaction is reflected in the mirror; we are constantly aware of a doubling effect in the scene.

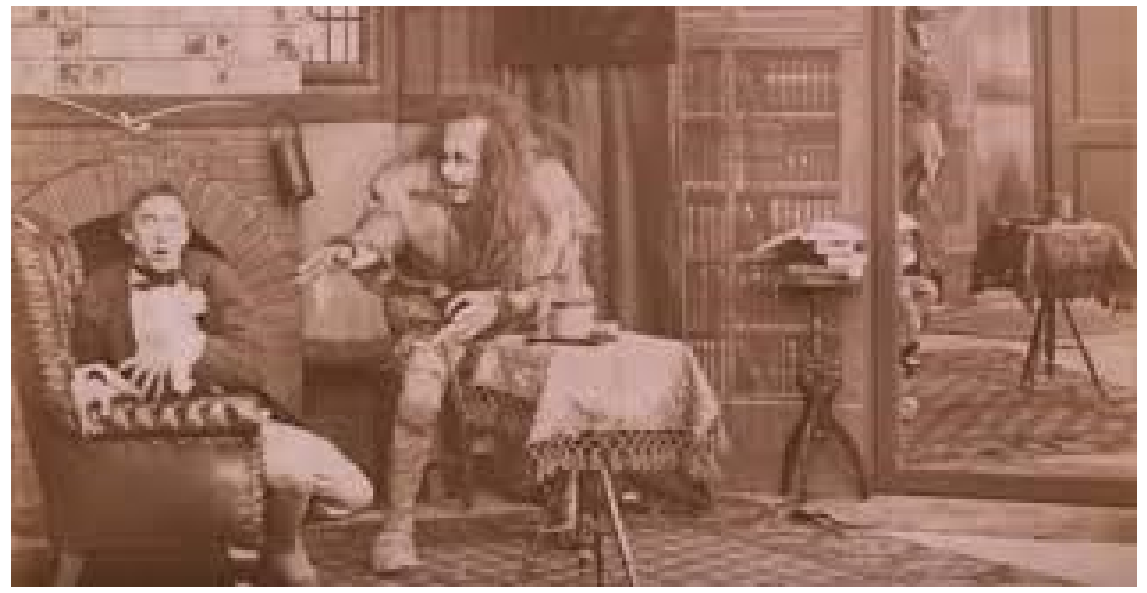

Elizabeth enters, but is quickly ushered away by Frankenstein before she can see the hiding Monster. After this, they struggle briefly in front of the mirror, after which the Monster ends up seeing his own reflection. He recoils in disgust, as if conditioned to hate ugliness; this performance could be read as a moralistic condemnation of his very existence - evil recognizing itself as such, rather than rejoicing in its wickedness. This is reinforced by "Frankenstein's better nature asserting itself" on the bridal night, which sets the stage for the final confrontation with the Monster. After a wedding reception in their living room, and a quiet moment with Elizabeth, the Monster once again threatens Frankenstein, who finally asserts himself and chases him back into the parlour. Afraid for the first time, the Monster backs into the room, looks at himself in the mirror, and disappears into it - now only appearing as its own reflection. For a few striking seconds, Frankenstein only sees the Monster as he stares into the mirror. Eventually the Monster disappears, and Frankenstein's own reflection appears; he touches the glass in astonishment, as if to confirm the Monster is truly gone. As he celebrates with Elizabeth, the ending appears to be happy - but those few seconds suggest the Monster will always be a part of Frankenstein's psyche. 


\section{Conclusions}

Overshadowed by the cultural impact of James Whale's 1931 classic, Edison's adaptation of Frankenstein is still a hidden gem of American silent horror. It is an example of the era's "one-reeler" standard, as well as the tendency towards adapting classic literature for familiar content. Its stylistic qualities are customary for the era, including the use of distant framing, frontal staging, studio sets and theatrical acting. Its special effects, were highly innovative for the time; the creation of the Monster is advertised in Moving Picture World as "possibly the most remarkable ever committed to a film," and a "photographic marvel.” Although trade press publications were in the business of advertising for producers and companies, and are not indicative of any film's quality, these sequences and techniques were still indicative of the many possibilities of the growing medium.

As with many American films from the 1910s, Frankenstein was an adaptation of pre-existing material. Its director, J. Searle Dawley, had a long career in adaptation, from fairy tales (Hansel and Gretel, Snow White) to seminal novels (A Christmas Carol, Anna Karenina). Adapting respected properties and well-known stories was done to quell concerns about the emerging medium of film and attach a level of prestige where others disregarded it as a frivolous spectacle. This would be an instance of accruing status; as Linda Hutcheon observes, "one way to gain respectability or increase cultural capital is for an adaptation to be upwardly mobile" (91), as if the artistic equivalent of a social climber. In this period, adaptation also worked as a form of shorthand; most viewers would have heard the story before seeing the film, where the "language" of film was still being developed. The first intertitle also describes the film as "a liberal adaptation of Mary Shelley's famous story," acknowledging both the wide circulation of the novel, but also the artistic freedom of filmmakers to re-interpret the material. It is also commonly recognized as the first cinematic adaptation of Frankenstein, which is a significant claim to make, given the countless reworkings of the story across the globe since then. This relates to consistent efforts to preserve as many silent films as possible, as one discovery could alter accepted 
histories of adaptation, whether it is from a book, a play, or other medium of storytelling.

What makes Frankenstein special in the context of silent horror cinema is its lack of "overtly" horrific elements or "repulsive situations," according to industry publications and company ads. Horror is a deeply subjective feeling; who is to say filmgoers did not feel disgusted by the creation of the Monster, or frightened by its appearance and actions? However, spectator reactions are not what needs to be stressed, but rather the conscious elimination of gruesome - and bleak - content in favour of "the force of true love [being] vividly presented." Rather than including Elizabeth's murder, the implied suicide of the Monster, and/or the death of Frankenstein in the Arctic Circle, the film ends quite happily. Frankenstein and Elizabeth are married, and the Monster simply disappears; presumably to both avoid depicting violence and to highlight the vanishing effects practised in trick films.

The film's advertisements also emphasize the "mystical and psychological elements" that are featured over more questionable content. The film's narrative and style, as well as sequences from the novel provide ample evidence of this focus. With regards to the material's treatment of mysticism, both versions of Frankenstein seek knowledge that is not answered by the modern sciences of their day. In the novel, Frankenstein gravitates toward chemistry as a branch of natural philosophy, taken by a charismatic professor and the potential rewards of investigating the "recesses of nature," which leads to the creation of the Monster. He "entered with the greatest diligence into the search for the philosopher's stone and the elixir of life" (Shelley, 23); he acknowledges his family is "not scientifical" (23), and calls himself a disciple of Albertus Magnus, a 13th-century friar who wrote treatises on alchemy and chemistry. In the film, Frankenstein leaves for college, and discovers "the secret of life" two years later. He mixes ingredients into a bowl, accompanied by a skeleton straight out of a Méliès film, and essentially cooks the Monster in a smouldering cauldron. Through these predilections, motivations, and strategies, Frankenstein could just as easily be called an alchemist as a scientist, justifying the mystical elements as advertised by Edison Studios and Moving Picture World. 
If there are any specific disciplines the film is interested in, they are psychology and theology, given the notable focus on the mental state of its characters, and the treatment of Frankenstein as a God-like creator. As shown in the intertitles, "the evil in Frankenstein's mind" is responsible for creating the Monster, and "the creation of an evil mind is overcome by true love and disappears." While this is a facile moralistic play on Frankenstein's mental condition, it is does seem to argue that good and evil can simultaneously influence one's behaviour. Frankenstein wants to cure all diseases, but his transgressive desire to create life corrupts the process and makes a misshapen monster instead of "the perfect human being." Put differently, Frankenstein's conscious efforts are undermined by unconscious wickedness, which can be interpreted through the Freudian psychical schema of the id, ego, and super-ego. While this cannot fit neatly onto any moral spectrum, if one's instinctual drives can be associated with the unconscious, then the evil in Frankenstein's mind that creates the Monster can be connected to his id. Essentially, this immoral desire to create life overrides Frankenstein's conscience or super-ego - resulting in the failure of his ego to balance his purer intentions and darker impulses.

All things considered, calling Frankenstein a silent horror film is contestable. It is "silent" in the sense that there is no dialogue or diegetic sound, but it came with suggested musical cues from operas and songs, and restorations have included original soundtracks by composers. As Rick Altman notes, "scholars have for years pursued their arguments in favor of cinema's visual nature" (6); it is crucial to interrogate the ways in which contemporary audiences would have listened to a film such as this. Recommended music included several pieces from the 1821 German opera Der Freischütz, possibly including the famous "Wolf's Glen" sequence, called "the most expressive rendering of the gruesome that is to be found in a musical score" (958) by music critic Gustav Kobbé. It also "[mixes its] classical fragments with morsels in varied lighter styles...[including] a sentimental salon piece and an oldfashioned parlour song" (Marks, 186), balancing music that elicits the horrific with tender melodies, as well as tracks that suggest the gentrified society to which Frankenstein belongs. 
The generic label of horror is further questionable. Frankenstein has had such an indelible effect on popular culture - especially through the Monster - that its association with horror iconography and tropes is essentially impossible to deny. But at the time, there was enough of a concerted effort to avoid the label that Moving Picture World explicitly said that filmmakers actively removed those situations. It is also telling that the "horrific" is associated with the "repulsive," which evokes disgusting images that might make one feel ill. But there is a deeper affective character to horror that these blurbs do not quite recognize; it also deals with fear, dread, suspense, and other related emotions. While there may not be any gruesome content, or any morally questionable subject matter, the Monster especially is a scary sight to behold. And if the spectator is in any way disposed to imitate the reactions of the protagonist, Frankenstein's horror at his creation may have seen like reactions in the audience. 


\section{Chapter Two:}

\section{From Whence He Came:}

\section{Monsters and Folklore in The Golem: How He Came into the World (1920)}

The familiar content of silent horror also extended to the German cinema of the 1920s.

Like the "trick films" and literary adaptations we have discussed, monsters and the supernatural feature within a broader stylistic tradition called German Expressionism. Also reflected in architecture, literature and painting, Expressionism sought to reflect the psychological complexities of the human mind through the representation of space and place. The set design reflects this tradition: interiors and exteriors are jagged shapes, and chiaroscuro exaggerates the play of light and shadow, which distorts our idea of the world as a result. As film historian Lotte H. Eisner observes, "Mind, Spirit, Vision, and Ghosts seemed to gush forth, exterior facts are continually being transformed into interior elements, and psychic events are exteriorized. Is this not precisely the atmosphere we find in the classic films of the German cinema?" (15).

Some scholars have also noted the influence of World War I on German films post-1915. During this time, the output of their film industry had been interrupted due to the diversion of resources and mandatory enlistment. Although the German cinema of the 1920s also includes realist dramas, comedies, and romances, the horrors of modern warfare and their collective grief resonates strongly with the psychological undertones of Expressionist cinema. As cultural critic Siegfried Kracauer points out, this had a galvanizing effect: "[Expressionism] may have cast a spell over many Germans upset by the breakdown of their universe... with faith in man's power to freely shape society and nature" (68). On the other hand, these films developed strategies to engage with this suffering without explicitly recreating what led to it. For example, instead of depicting famous battles, they "expressed" cultural anxieties through genre templates, harsh makeup, distorted environments, etc. Film historian Anton Kaes characterized Expressionist films as "post-traumatic...reenacting the trauma in their very 
narratives and images" (3), foregrounding the unique power of visual storytelling to process the effects of such a catastrophic event. The term "reenacting" also suggests a psychological exercise, a kind of exposure therapy by processing grief through the allegory of their stories. It is this broader context that brought The Golem: How He Came into the World (Paul Wegener, 1920) into being.

Between 1915 and 1920, Paul Wegener directed three Golem films - The Golem (1915, with Henrik Galeen), The Golem and the Dancing Girl (1917, with Rochus Gliese), and The Golem: How He Came into the World (1920, with Carl Boese) - and played the titular creature. The first Golem is partially available at German film archives; Dancing Girl is considered lost. How He Came into the World exists in its entirety, having undergone several preservation efforts, including a digital restoration as recently as 2017. It is an early, though not textbook example of German Expressionism, and includes several of the narrative and stylistic trends that are associated with the movement. The film also features a monster figure, which threatens the established order, and must be defeated to restore normalcy. However, this intersects with the Golem's complicated legacy as a defender of the Jewish people, and its history with Kabbalah, a sect of mystic Judaism. As we have seen with Frankenstein, silent horror films have emphasized mysticism over horrific content. Moreover, since the beginnings of cinema, magic has been associated with producing miraculous effects.

The Golem films were also loose adaptations of Gustav Meyrink's 1915 novel, The Golem. The story revolves around an unnamed narrator who can experience the consciousness of Athanasius Pernath, a jeweler in the Jewish Quarter of Prague. Instead of representing the Golem as a menacing creature that wreaks havoc, in the tradition of the Universal horror films, Meyrink adopts a more mystical approach. He characterizes the Golem as a "spiritual disturbance" (44), which "[rises] in the form of a wraith that appears to our senses in the guise of a human entity" (44), rather than the man of clay in legend. The fact that he is not molded from clay is significant here; rather than being formed by an intelligent being for a particular purpose, as human beings were in certain creation myths, this 
version of the Golem haunts humanity with independent agency, emboldened by their transgressions. Rather than foregrounding the Golem figure in the novel, there is instead a pervasive fear of the occult, which influences human behaviour throughout the narrative. Schemajah Hillel, a wise mentor figure to Pernath, even says that "It's only the supernatural, the Kischup, that can strike terror into the souls of man" (70), emphasizing the dangers of mysticism in the context of Jewish folklore. The film takes place in medieval Prague, rather than the $19^{\text {th }}$-century, which allows it to incorporate Rabbi Judah Loew ben Bezalel as a central character. A prominent $16^{\text {th }}$-century Jewish mystic, Rabbi Loew is a crucial figure in Kabbalist mythology, and often cited as its creator for the protection of Prague's Jewish community.

The German company PAGU (Projektions-AG Union) handled production duties for The Golem: How He Came into the World. It was distributed in Germany by UFA (Universum Film Aktiengesellschaft), PAGU's eventual owner, and in the United States by Famous Players-Lasky Corporation. It established the psychological and stylistic trends that we see in later German Expressionist films, but it relates to national and cultural identity in historically unique ways. As cultural historian Anna-Carolin Augustin writes for the Jewish Museum of Berlin, these films "reflect...the monstrosity of the First World War," especially the creation of modern industrial weapons. As with other films we have discussed, The Golem features a monster and depicts situations that could be considered fearsome or unsettling. However, it also exists at a complex intersection of Kabbalist mysticism, national identity, and artistic experimentation, showing a wide-ranging interest in the iconography and affective power of silent horror cinema.

\section{Unearthing the Legend: Finding and Restoring the Golem Films}

The first film, The Golem (German: Der Golem), was written and directed by Paul Wegener and Henrik Galeen, and released in Germany on January $15^{\text {th }}, 1915$. An early motion picture company from Berlin, Deutsche Bioscope GmbH, produced the film. While How He Came into the World has an 
explicitly $16^{\text {th }}$-century setting, the milieu of The Golem is curiously ambiguous. Danish film historian Casper Tybjerg notes that "surviving stills show actors in more-or-less contemporary clothes" (21), despite the medieval town of Hildesheim serving as a backdrop for exteriors. Instead of committing to a specific era, these mismatched elements made their depiction of Prague seem oddly anachronistic. Moreover, although Meyrink's novel ostensibly inspires the film, “[they] appear to be entirely independent conceptions, sharing only the title and an interest in the legends of old Prague" (Tybjerg, 21).

Along with ancillary documents from the films, such as promotional materials and original scripts, the Stiftung Deutsche Kinemathek in Berlin possesses fragments of The Golem, otherwise considered lost. According to Lost Films, an online catalog developed by the Kinemathek, they have “108-meter fragments" in their collection, along with "97-meter fragments" preserved on DVD copies. Although the commentary is sparse, and the page only features a couple of stills, this project represents the enduring international effort to identify and preserve these pieces of film history.

Although The Golem exists in fragments, The Golem and the Dancing Girl (German: Die Golem und die Tänzerin) is considered completely lost. Co-directed by Rochus Gliese and Wegener, and again produced by Deutsche Bioscop $\mathrm{GmbH}$, it is a self-reflexive film that acknowledges the existence of its predecessor and appears to be explicitly comedic. Casper Tybjerg calls it a "meta-filmic spoof" (21), wherein "a famous dancer...goes to the cinema to see Der Golem, and is so taken by it that she contacts the film studio to buy the Golem figure" (21). A fictional version of Wegener ends up falling in love with the dancer and dresses as the figure at a party. As a potential example of silent horror cinema, it sounds intriguing for all the reasons it may diverge from this label. It appears to deal with a spectator's fascination with horror iconography, specifically the figure of the monster, and the apparent prop used in its portrayal. Its disappearance is even more disappointing for its generic complexities; as early as 1917, a film is satirizing the conventions through which we define films. 
Although there have been other adaptations of the Golem mythology, including stage plays, the selfreferential nature of Dancing Girl - including the plot point of purchasing the Golem figure - means that the parody largely relies on the iconography of the first film, rather than other iterations.

Unlike the first two films, The Golem: How He Came into the World (German: Der Golem, wie er in die Welt $\mathrm{kam}$ ) has undergone several international preservation efforts, with home media releases in at least five countries. The first restoration occurred in 1977 as an assignment for renowned German composer Karl-Ernst Sasse. Musicologist Sylvain Ménard mentions the tone of Sasse's compositions, from "elegiac and festive" to "somber and gothic," in a manner that he characterizes as "often modern" (translated from French, n. pag). The second major restoration is one that is readily available on home media; in the United States, prestige distributor Kino Lorber published it on DVD. In 2018, the Friedrich Wilhelm Murnau Foundation included The Golem: How He Came into the World on their list of new DCPs (Digital Cinema Packages) from their "Digitization Offensive" of silent films. In contrast to the previous undertaking, this version has not been made available on an updated home media format, but rather exclusively as a digital file for special exhibitions. As such, it shifts away from prioritizing home media releases and emphasizes digital-only formatting for future preservation efforts.

Different editions of How He Came into the World also vary in length. One United Kingdom edition, published by Eureka Video in 2007, runs 84 minutes, while another - released by Dark Vision in 2001 - runs 64 minutes. Removing a third of the film would change the narrative context significantly, but this is not uncommon in film history. Complete prints are found in dusty basements, and re-discovered portions of films are added to extant copies. This also attests to the control home video companies have over these silent films; since they are in the public domain, they do not have to spend exorbitant amounts of money on the rights. As a result, even independent organizations with adequate publishing resources can pick and choose which elements of the story to include or remove, 
or which frame rate to render it through. While they have previous home video releases or screening details to work off, there is still an element of creative freedom there, should they wish to exercise it.

\section{Dreams of Prague: Adapting The Golem from Novel to Screen}

The Golem, written by Austrian author Gustav Meyrink, was first published in eight installments by the German magazine Die Weissen Blätter, from December 1913 to August 1914. Independent German publisher Kurt Wolff handled the first novel edition in 1915. It is Meyrink's first novel; he had previously published a selection of short stories and collections, including The Hot Soldier and Other Stories (1903), and The Waxworks (1907). It is a dreamlike story, more concerned with the affective character of the Ghetto than a straightforward narrative revolving around the Golem. While characters reference the folkloric legend of the clay man brought to life by a rabbi, this version is a phantasmagorical manifestation of the moral ills that occasionally arise in the town. He is not a protector, but a myth that becomes real when evil returns. As the protagonist's friend Zwakh mentions, "Always they treat it as a legend, till something happens and turns it into actuality once more" (41), such as crimes against one's fellow man.

In contrast with the film, the novel includes uncanny dream sequences, which unsettle traditional ideas of narration. For instance, the unnamed narrator goes to sleep and occupies the consciousness of Athanasius Pernath, an inhabitant of the Ghetto. These "dreams" constitute a liberating wandering for the narrator, who also suffers visions of stones that come to life and harass him. They appear "like monstrous, slaty-hued crayfish...agonising to tell me tidings of great importance" (6), occupying this "dim twilight of dreams" (6) separate from his visions. This spatial and temporal disorientation, which returns several times throughout the novel, is reminiscent of the aims of German Expressionism, especially as it relates to the expression of character psychology. However, this engagement of different planes of awareness - from waking life to semi-consciousness to dream states - might have been too abstract for Wegener. 
As with The Golem: How He Came into the World, several scholars have accused Meyrink's novel of being anti-Semitic. He often uses offensive descriptors for wicked characters; Aaron Wassertrum, the local shopkeeper, is described as having a "staring, greasy countenance with...goggle fish eyes and [a] sagging hare-lip" (10). A local student, Charousek, says that Wasserstrum's son, Dr. Wassory, "[revels] in the idea of himself as the arch physician appointed to pronounce upon [his patients'] weal or woe" (31), accusing him of manufacturing illnesses. These are inescapably racist characterizations of the Wassertrums as duplicitous and money-hoarding, which darken any reasonable suspicion of malpractice. Charousek is also envious of their wealth, feeling entitled - as an educated young man - to a similar measure of success. Legal and literary scholar Jeffrey Miller argues that Meyrink - and Yiddish writer H. Leivick - situate the golem "as [a] highlight in an atmosphere of insidious racist violence" (192), exacerbated by this festering hatred. There are other competing claims around the novel's bigotry; cultural historian Scott Spector argues that it "was the projection of a certain reading of the city [and] a threatened generation of Prague's German speakers" (6). On the other hand, E. F. Bleiler says that "Meyrink portrayed saints as well as villains, and he said no more about the Ghetto than has been said about ghettos of all sorts by generations of sociologists" (xvii).

Because the monster of the novel and film is a figure from Jewish mythology and serves as a defender of their people, stories that address or re-tell the story will potentially involve harmful stereotypes, which reflect broader cultural attitudes of the time. Frankenstein's Monster, by contrast, is not a figure from any religious tradition; although the Golem legend may influence his character, he is an original creation of Shelley's. There is no concern over the portrayal of the people he protects or threatens, but rather that he is a collection of body parts - a process considered "repulsive" at the time of Edison's 1910 film, resulting in a reworking of the Monster's origins. By contrast, it is not controversial that Rabbi Loew makes the Golem from clay, as this is a common feature of creation myths, but rather that a devil figure assists him. As cultural scientist Klaus Davidowicz notes, there are 
Faustian elements involved in this process, which suggests that Jewish mystics collaborated with the devil - rather than God - to create life, going against traditional Kabbalist thought.

The Golem figure in Meyrink's novel is explicitly associated with feelings of horror. The narrator's friend Zwakh says that "the terror of [a Golem encounter] is too strong for either explanation or excuse" (43), calling it a "spiritual disturbance" (44) caused by a ghost who appears in human form. Although these Golem appearances only occur every thirty years or so, they leave an indelible impression on the collective consciousness of the Ghetto, as if they purge it of all the evil that accumulates in the interim. In this version of the legend, "the whole mass of stagnant thought infecting the air of the Ghetto needs clearing" (45), according to its residents, and the Golem serves this function. However, because this problem is associated with characters that are described using xenophobic language, this element of purging collective evil assumes a deeply uncomfortable dimension. On the other hand, this may also encompass the hatred Charousek feels towards Wassertrum and Dr. Wassory, rather than a racially motivated attack on Meyrink's part. In any case, the function of the Golem in Wegener's film is much more straightforward, and faithful to its purpose in Kabbalist mythology, although the intervention of Astaroth and Faustian connotations in its creation questionably influences its depiction.

Studying the adaptation of Meyrink's Golem to Wegener's film is a challenging task, largely because of their significant differences in plot and tone. Although it is possible to make connections between the portrayal of the Golem, the depiction of Prague - albeit in different times - and the treatment of Jewish mysticism, the narratives are very different. As German studies scholar Cathy S. Gelbin observes, “On the plot level, Wegener's only borrowing from Meyrink regards the relationship between the rabbi's daughter Miriam and her non-Jewish lover" (115). Because the trilogy of Golem films overlaps with the publication of Meyrink's novel, some scholars have suggested that Wegener and Meyrink may have inspired each other. Literary scholar Elizabeth R. Baer writes that "the 
intertextuality may have worked in both directions: the early Wegener film influenced Meyrink, who began writing his novel around 1906, and Meyrink...influenced the 1920 Der Golem" (51). Here, we see similar texts - from different media, no less - influencing each other's development, and the aesthetic choices that each work makes as a result. Moreover, Wegener's series is commonly considered a trilogy, although they are only really connected thematically. In any case, although the relationship between the novel and the film remains disputed to this day, there was some connection between the two in the popular imagination, further underscoring the close relationship that international silent horror had with the literature of its time.

\section{The Mystic Arts: Kabbalist Practice and the Birth of the Golem}

The title cards introduce the film as "Pictures after events from an old chronicle," foregrounding their adaptation of the Kabbalist legend over Meyrink's novel. This also explicitly frames it as a period drama; set in medieval Prague as opposed to the $19^{\text {th }}$-century environs of Meyrink's novel, it takes advantage of its stylized Expressionist aesthetics to further distance itself from a realistic "present." It begins in earnest with "The learned Rabbi Loew [reading] the stars that misfortune threatens the Jews," and encouraging his community to prayer. Here, the practice of divination is associated with wisdom, taken seriously as portending danger. These fears are confirmed when the Imperator issues a mass eviction notice, accusing the Jews of practicing "black magic" and other crimes. In response to this threat, the Rabbi seeks to summon "the dread spirit Astaroth" amidst favourable astrological signs to bring the Golem to life, which he believes will save his people. This is where we may begin to identify the film as "horror"; the audience is meant to fear the power and appearance of Astaroth, and the monster figure becomes an extension of this initial act, with his eventual rampages attributable to this forbidden evocation of demonic entities.

At the heart of this process is Kabbalah, a sect of Jewish mysticism that emerged in $13^{\text {th }}$-century Europe, although some argue for its more ancient origins. Commonly associated with Western 
esotericism, Jewish philosopher Moshe Idel defines Kabbalah as "not only as a collection of fragments of esoteric lore of hoary antiquity but also as an open science to be furthered by the experiences of the individual and his ability creatively to interpret the Holy Scriptures or other canonic texts" (254). In the film, the individual experiences of Rabbi Loew, as a "father to the community" of the Jewish people, have necessitated the "open science" involved in the Golem's creation. Moreover, it is a responsibility of the Tzaddik, or Hassidic spiritual leader, to defend his people from outside threats, in the absence of a messianic savior. As Jewish scholar Byron L. Sherwin observes, “various forms of mystical magic are to be employed to redeem the community from the evils that threaten and beset it" (209), which is typical of prophetic Kabbalah. As a result, this power is not to be used lightly, even at the whims of a learned individual, but rather as a last resort in crisis - Loew asks his assistant to "Guard this secret with your life."

When comparing the Golem with Frankenstein's Monster, their respective circumstances are very different. In the teachings of Kabbalah and the start of the film, the Jewish people of Prague intend the Golem to be their protector. In a way, this is antithetical to Frankenstein's Monster, who was born out of unbridled scientific curiosity and immediately feared. Christian theologist Alfred D. Byrd writes, “Kabbalists saw human use of God's power to create life as good; Mary Shelley, as a potential source of evil" (50), drawing comparisons between these figures and modern genetic engineering. Here, morality intersects with faith, as both traditions view this power through different ethical frameworks. Although Mary Shelley does not stand for Christianity, when the Monster says, "I ought to be thy Adam, but I am rather the fallen angel” (73), he sees himself as a mistake of creation. Perhaps the difference is intent; while Frankenstein's Monster resulted from self-indulgent experimentation, the High Rabbi was expected to take measures to protect his community. Byrd further notes that "Dr. Frankenstein's work, which stemmed from sinful pride that took no responsibility for what it had 
produced, ended in tragedy" (50), whereas in Kabbalist lore, "a golem's creation was entirely an act of meditation on God as Creator" (49).

This depiction of the Golem, explicitly related to Kabbalah, is often marketed as ambivalent. The streaming service Kanopy describes the Golem as "sculpted of clay and animated by the mysterious secrets of the Kabbalah...performing acts of great heroism, yet equally capable of dreadful violence" (n. pag.) In Moment Magazine, journalist Marilyn Cooper notes that the Golem is "brought to life through Kabbalistic magic; while the golem is often created with good intentions, or even to save the Jews, ultimately it runs amok and must be destroyed" (n. pag.) As a result, the mysterious forces of mysticism are open to corruption, whether from the human heart or demonic forces. In a way, this is very similar to Edison's Frankenstein; the Golem did not evolve from Rabbi Loew's sinful desires, but forces outside Frankenstein's (conscious) control corrupted any altruistic intent. In Kabbalist thought, a golem is considered potentially harmful, but not because of the creator's moral fallacies. The creator must be beyond reproach and capable of killing a corrupted golem. Religious historian Harry Freedman observes, "The person who makes a golem must be a skilled Kabbalist, learned and righteous...[they must] know how to control their creation, and how to destroy it should it turn dangerous" (137).

This intersection of mysticism, a monster figure, and its ambivalent moral character is eerily similar to Edison's Frankenstein, more so than Shelley's novel. While Shelley touched on the esoteric qualities of natural chemistry, the film explicitly relates the Monster's creation to alchemy. This mystical practice is reflected most clearly in the cauldron scene, where the audience is shown the Monster's molding from a concoction of disparate elements, taking full advantage of the cinema's capacity to show over literature's predilection to tell. These mystical qualities are also seen in the occult paraphernalia of Frankenstein's laboratory. Although not all Kabbalist traditions are associated with this, some branches did use supernatural resources. Frankenstein created his Monster from a collection of suspicious ingredients, but Wegener's Golem directly derived his power from a mystical 
amulet, the removal of which ultimately defeated him. As we will see, the power of the word "Aemaet" also links the life force of the Golem to ancient entities, whereas Frankenstein's Monster is earthen but blasphemous.

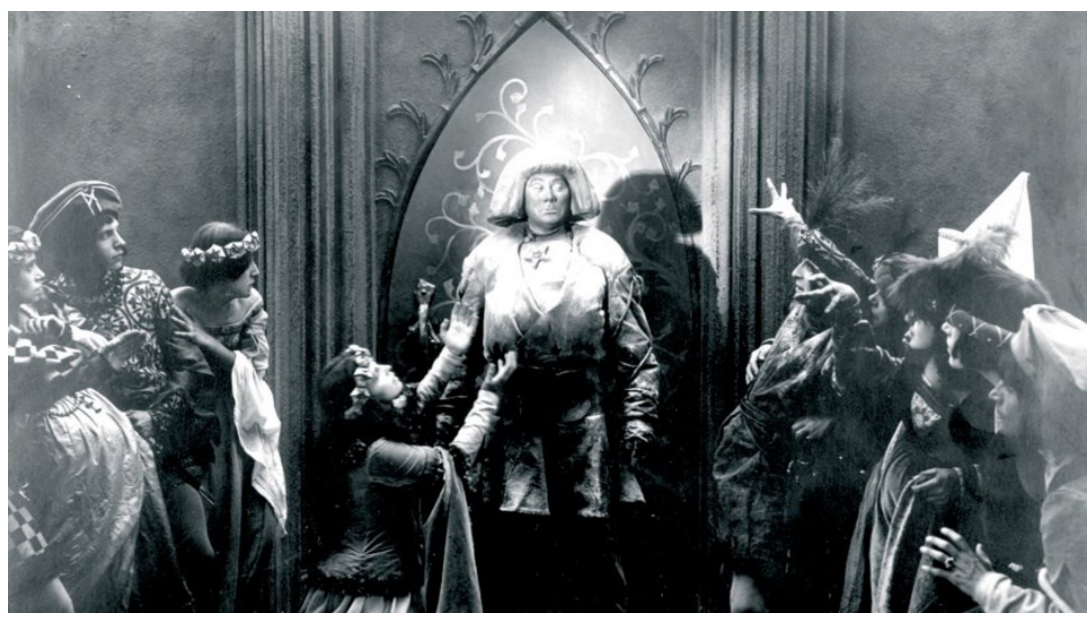

\section{A Philosophy of Monsters: The Golem and Noël Carroll}

It is also worth revisiting Noël Carroll's theory of monsters as necessarily repulsive and threatening, given the Golem's customary role as savior of the Jewish people. He specifically mentions the Golem in an exercise demonstrating the paradox of suspending disbelief in fiction. Here, the Golem is a monster figure the audience is supposedly afraid of but must acknowledge is not real. Alongside this belief that the Golem does not exist, Carroll argues, "given the required conditions for emotional response... [the spectator] believes that the Golem exists" (67). This element of belief is important here, as the Golem is not just a generic monster in horror cinema, but also a figure in religious mythology. As such, there may be a level of belief in this entity - at least in Kabbalah - that Frankenstein's Monster does not share, as he is wholly recognized as a fictional creation.

Carroll goes on to characterize the creation of a golem as an illicit practice, like the creation of Frankenstein's Monster. However, this approach ignores the permissible investment of godly power that Kabbalist thought associates with a golem as a benevolent figure. This is reinforced by the literal origin of Rabbi Loew's inspiration in the stars, traditionally associated with both divination and divinity. He notes, "Once the scientist, alchemist, priest, or magus acts on this forbidden knowledge - 
e.g., brings a golem to life - inestimable, maleficent power is released, and the consequent destruction becomes the stuff of the story" (127). This conflicts with the idea of "human use of God's power to create life as good" (50), as Alfred D. Byrd notes, wielded with a socially conscious purpose. This power is not forbidden in the hands of a learned mystic, and is "estimable" as a result, because they understand the nature of what they are wielding. Instead, film critic Steven Jay Schneider characterizes the Golem as "an unstable entity - his susceptibility to control by the demon Astaroth leads him to run amok" (96). Outside forces are responsible for the Golem's monstrous rampages, not Rabbi Loew whose intentions were relatively pure.

\section{Molded by Magic: The Creation of the Golem}

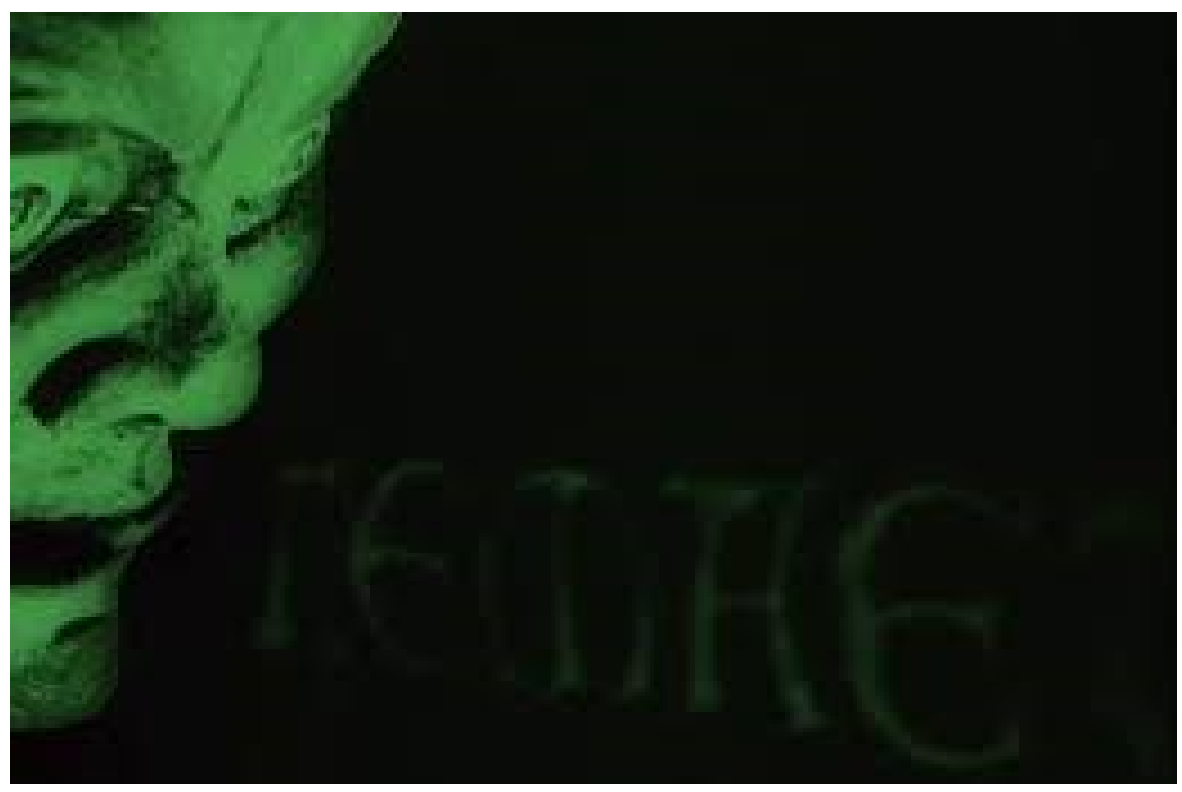

As with the creation scene in Edison's Frankenstein, the birth of the Golem in The Golem is a spectacular demonstration of Expressionist visuals, replete with allusive significance. Klaus Davidowicz observes that Rabbi Loew "follows the [Kabbalist] instructions to form a Golem... as a rescuer in a time of peril [which] comes from Rosenberg's Sepher Nifla'ot' (160), a collection of Hebrew stories. Along with his assistant, Loew draws a circle around himself in the middle of his laboratory and conjures the demon Astaroth in a striking light show, complete with balls of light and a 
fiery platform. As Astaroth emerges from the darkness to the left, he only appears as a disembodied head, a menacing expression plastered on his still stone face. Interspersed with close-ups of Astaroth, smoke billowing from his pursed lips, Loew pleads with him to speak the word that will give life to the Golem. Finally, the word “Aemaet" (meaning "truth”) emerges from Astaroth's mouth, and he disappears. The word is carefully written down by Loew, folded into an amulet, and pressed into the Golem's chest, which awakens him.

Although there are Kabbalistic elements to this ritual, Davidowicz argues that Loew is portrayed as a Faustian character, intertwining the hubristic qualities of the German legend with those of Jewish mythology. As a result, "Wegener turns Loew into a magician who does not use combinations of letters, but rather conspires with the devil to bring the Golem to life" (160). Astaroth is very explicitly a devil figure; while he does not use that moniker, angelologist Gustav Davidson calls him "a great duke in the infernal regions" (59), but more importantly, "[Astaroth was] one of the seven princes of Hell who visited Faust" (59). While this is from English tradition, rather than a German or Jewish theological framework, it is possible that Wegener was aware of this, and used this context to foreshadow his rampages. While he does use aspects of Jewish culture, such as "the emet motif from Chelm" (Davidowicz, 160), this use of Faustian legend revises Jewish mysticism as satanic and hubristic. Ultimately, "the [creation] scene evokes anti-Jewish prejudices where the Jews are said to be in league with the devil" (160), rather than God, who permits the careful use of such powers.

\section{Conclusions}

The mythology of Frankenstein's Monster has intertwined significantly with the Golem. Henry Frankenstein famously exclaims, "Now I know what it feels like to be God!” whereas “the golem's creation was entirely an act of meditation on God as Creator" (49), as Alfred D. Byrd argues. In both cases, the power to create life is God's mandate. Henry covets this power over his collection of body parts, and the ideal Kabbalist keeps God in mind when wielding their magic. As a result, while The 
Golem had a significant aesthetic influence on subsequent horror films due to the circulation of talent, it also engaged with similar questions of ethics. If someone creates a monster or something with the potential for evil, does their intention matter? Do their "acts of meditation" somehow purify their creations? In The Golem and Frankenstein, it certainly seems so; in the former, the demon Astaroth is responsible for the Golem wreaking havoc, not Rabbi Loew. In the latter, Frankenstein blasphemes God in his laboratory. In any case, their transmedial engagement with similar myths is worth looking at in the context of silent horror cinema, as both become film adaptations while first existing as novels and folkloric legends.

The Golem figure is also an integral part of traditional Jewish legend. Paul Wegener's series of Golem films, to varying degrees, address the complicated legacy of this mythology, as well as the Golem's capacity for benevolence and violence. As an example of silent horror cinema, The Golem: How He Came into the World may have influenced, and been influenced by, the various iterations of Frankenstein from 1818 to 1931 . Its foregrounding of a monster figure, and the terror that it generates, seemingly fulfills this generic mandate, but the Golem's conventional role as protector complicates this designation. Several other qualities define The Golem as a unique text, from its storied provenance, its integration of Kabbalist mythology, its use of magical themes, and its historical context in German cinema. In terms of the trilogy's survival, their histories are unfortunately typical of many silent horror films, given a lack of consistent resources and the ravages of time. However, the survival of World has given us a forerunner of German Expressionism, and one of the first feature-length monster movies.

Frankenstein's Monster is a wholly original creation of Mary Shelley, subsequently adapted for the screen by the Edison Manufacturing Company, as was typical of many one-reelers at the time. However, the Golem preceded both Gustav Meyrink’s 1915 novel and Wegener's films as a crucial figure in Kabbalist mythology. A mystical adjunct of Judaism, historical scholarship often connects Kabbalah with occult practices and feats of magic, permitted or not by God. In this context, the Golem 
inhabits a legacy as both protector of the Jewish people from oppression and an instrument of violence by evil forces. In the film, Rabbi Loew raises him in response to a celestial warning of persecution, but the demon Astaroth corrupts him in the process. While Meyrink's novel portrays him as a manifestation of the Ghetto's wickedness, Wegener's film is set in medieval Prague, steeped in the original context of Rabbi Judah Loew ben Bezalel's writings. Although it borrows elements from these sources, its creation scene reflects concerns that it depicts Jewish mystics as in league with the devil.

Although the Golem legend predates Mary Shelley's Frankenstein, The Golem had a significant influence on Universal's horror films of the 1930s. Karl Freund, the co-cinematographer of The Golem (with Guido Seeber), went on to shoot Dracula (Tod Browning, 1931) and Murders in the Rue Morgue (Robert Florey, 1932) for Universal, ultimately directing The Mummy in 1932. The Expressionist visuals he cultivated in his German productions are clearly on display in his American works, from the cavernous interiors of Dracula's castle to the Egyptian tomb of Imhotep. Both examples use cinematography and set design to exoticize the foreign Other, portraying them as mysterious and arcane as their unfamiliar surroundings. Moreover, Dracula (Bela Lugosi) and Imhotep (Boris Karloff) are immediately threatening; once pretenses are done away with, their evil motivations come to the fore. They are not created to serve or protect; in fact, their surrounding communities fear them as legendary monsters.

Due to their similarities and close history, Frankenstein and the Golem also have an intertextual relationship and many common characteristics. Their creators make them against their will, and they ultimately reject their creators after becoming more aware. Noël Carroll's theory of monsters is again problematic here, as his qualification that they are necessarily repulsive and threatening does not work with the Golem's role as savior of the Jewish people. Moreover, psychiatrist Fernando Espi Forcen notes that "In Ashkenazi Jewish lore, a golem may carry out tasks assigned by its creator and function as a servant" (11), rather than a monster that wreaks havoc from the start on a group of characters. 
Magic is also a common element in both Meyrink's book and Wegener's film. They both tie it to the supernatural forces surrounding the Golem, whether benevolent or maleficent. In the novel, Miriam characterizes magic as one of two dimensions of Kabbalah, along with what she deems "the abstract." She observes that "The magic side is a gift, while the other may be acquired, though only with the wise help of a teacher" (170) and associates it with performing miracles. Controversially, we see this ambivalence in The Golem: How He Came into the World, where Rabbi Loew uses magic to acquire knowledge and raise the Golem, but only through association with a devil figure. As Wegener sets the film in medieval Prague, and Meyrink sets the book in $19^{\text {th }}$-century Prague, the practice of magic is much more overt - and perhaps credulous - in the former, rather than the latter, which treats it with a superstitious hesitation. The spectacular creation of the Golem is also like the "cooking" of Frankenstein's Monster in Edison's film, using special effects to portray the ritual necessary to summon and converse with Astaroth - if not to mold the Golem.

The Golem: How He Came into the World is a significant example of silent horror cinema. As we have seen, the Golem is a figure that could be considered fearsome or unsettling, despite its role as a defender of the Jewish people. Schemajah Hillel and Zwakh both refer to the supernatural and the Golem as having the capacity to terrorize, which connects with Noël Carroll's assessment of monsters in horror fiction - although he is not necessarily repulsive. Although it is an adaptation of the novel in name only, its German Expressionist tendencies - externalizing the darkness of character psychology into the environments of the film seem especially well-suited to the aims of its source material. 


\section{Chapter Three:}

\section{A Satanic Sabbath: \\ Witchcraft and the Devil in Benjamin Christensen's Häxan (1922)}

Film historian Kendall R. Phillips argues that "[p]rior to 1931, at least when seen through a discursive frame, there were no horror films - the language of horror had not yet solidified into a definable genre" (3). In terms of paratextual elements like promotional materials, this is true; for instance, Phillips mentions that advertising for James Whale's Frankenstein was among the first to use these specific terms. Over time, audience awareness of the horror film would come to be associated with certain supernatural creatures, circulated internationally through these cinematic narratives. As film scholar Wheeler W. Dixon notes, "nearly all of the major thematic constructs that still fascinate us today - the man-made monster, the vampire, the pact with the Devil - date from this early period of experimentation" (3). We have studied the former with regards to Edison's Frankenstein and Paul Wegener's Golem films, and the vampire has held considerable interest, from the trick films of Georges Méliès to Universal's Dracula (Tod Browning, 1931). The Devil is not so widely understood as a movie monster, possibly due to his near-ubiquity in every manifestation of our culture. The pact is certainly a significant element in this mythology - a mutual agreement based on terms that the Devil presumably manipulates. If there is another consistent element here, it is the ultimate fallibility of humanity. While Dr. Frankenstein and Rabbi Loew create monsters that are quite complicated, the Devil is understood as the evil orchestrator of our demise through temptation and malice.

It is of further historical interest that these figures still endure as recognizable archetypes, given that they are situated within the medium's "period of experimentation." As the silent horror filmmaker investigated this subject matter alongside the gradual discovery of what frightened audiences, they ended up enduring as emblematic characters of horror. As Kendall R. Phillips observes, "the elements that constitute much of what we call "horror" were already present [before 1931]" (3) before the 
marketing for Universal's monster movies popularized the term. These elements include such figures as vampires and the Devil, and while scholarship had not yet consolidated these conventions into a cinematic generic framework, they were already very present in horror literature and drama. Above all, there was an awareness of the emotional effect they had on audiences, connecting film with the broader contextual web of horror in other media.

This chapter will address how Häxan (Benjamin Christensen, 1922) incorporates these popular archetypes of horror cinema, specifically witches and the Devil, in a genre framework that synthesizes aspects of the documentary and period drama. At times, it is hard to tell where fiction ends, and education on myth begins - due to the spectacular presentation of its material - so an episode-byepisode treatment of this relationship will be necessary in order to understand how the film approaches its content. This content was especially controversial at the time; Dixon characterizes the film as "a direct attack on conventional religion" (14), intending to upset traditional attitudes rather than capitulate to the status quo. Its "scenes of nudity, sadism, and violence, complete with a Black Mass" (14), were objectionable enough to warrant the film's suppression, as it is one of the "most often censored films of the early period" (14). This conflicts with other silent horror films, such as Edison's Frankenstein, which removed content from its source material that the producers themselves considered distasteful. As far the film's subject matter, medieval superstitions exist alongside human cruelty. There are people who believe in the Devil and witchcraft, but some - possibly those with more power - inflict torture because they enjoy it. This is not to say that Christensen enjoys torturing people, but that he sensationalizes these sequences, exploiting the inability to look away from horrific scenes and actions. Dixon associates this with freedom and artistic license, especially as opposed to commercial studio work. For instance, Christensen moved to Hollywood after Häxan was recognized internationally, but encountered "an all-consuming interest in the bottom line" (20), which pressured him to make a series of subpar horror features. 
As with Frankenstein and The Golem films, Häxan is a liberal adaptation of its source material, a $15^{\text {th }}$-century treatise on witch hunts called the Malleus Maleficarum. Written by controversial Catholic official Heinrich Kramer, the text was "the seminal document that systematized Christian doctrine defining witchcraft as heresy, and women's sexuality as satanic" (Fritscher and La Vey, 37). Given Dixon's mention of nudity as an example of sensitive content in the film, these elements are still relevant to scholarship today. Moreover, given Häxan's censorship troubles in the United States and elsewhere, its contemporaneous difficulties point to an enduring discomfort with female nudity perhaps exacerbated by the moving image. Notably, this was not why Christensen moved to Hollywood; instead, he "was forced out of the Scandinavian film industry with a damaging reputation for extravagance" (Horak, n. pag). It is of further interest that the offer given to him by American producers was quite attractive, and motivated by Hollywood's new acquisition policy, to buy up (and neutralize) non-American talent to strengthen the American film industry.

Since its release in Sweden on September $28^{\text {th }}, 1922$, Häxan has been restored multiple times by the Swedish Film Institute, with The Criterion Channel publishing its most recent print on DVD and Blu-ray on October $15^{\text {th }}, 2019$. Although its cast and crew are mostly Danish, this provenance - as well as its production by Svensk Filmindustri - attest to its importance as a Swedish cultural object. As film historian Laura Horak observes, “Christensen aspired to the artistry [of the Swedish Golden Age's directors] but wanted to overturn traditional narrative structure” (n. pag). He saw the international success that films by Victor Sjöström and Mauritz Stiller were achieving, and wanted to work within that national system, while simultaneously subverting established modes of filmmaking. Moreover, because of World War I, Christensen no longer had the same opportunities in Denmark due to the decline of its domestic film industry. Although the financial fallout from the film's expenses ruined his chances of ingratiating himself in the Swedish film industry, Häxan's experimental approach to its horrific content has firmly established its legacy as a genre touchstone. It remains to this day an 
unnerving, but aesthetically powerful testament to the influence that witchcraft and the Devil have had - as enduring monstrous figures - from the Middle Ages to the present day.

\section{A Discovery of Witches: Restoring Häxan through the Ages}

Häxan's first major restoration was a project of British filmmaker Antony Balch. Re-titled as Witchcraft Through the Ages, which has often been a sub-title for the film, Horak notes that it was "reedited... [with] added narration by William S. Burroughs and a jazz score by percussionist Daniel Humair" (n. pag), which dramatically changes its storytelling and musical context. With many silent films, the selection of dialogue and music is instrumental to the effect the filmmaker hopes to achieve, so these alterations make sense, given that it is a filmmaker who is implementing them. This edition was also an abbreviated 74 minutes, omitting some of the educational lectures at the beginning; it was also transferred at 24 frames per second, as opposed to the 18-20 fps transfers of subsequent editions.

The Swedish Film Institute completed another large-scale restoration in 2016. In an article published on the SFI's official website, Christopher Mair spoke with Joakim Högberg and Fredrik Rundqvist - the lighting designer and materials manager, respectively - on the preservation. Above all, they stressed the importance of being faithful to the original presentation of the film, from an imagistic perspective. Through this process, "scratches and other damage are removed, possibly clipped or found sequences are reintroduced, bleached colors are corrected, and more" (SFI, translated from Swedish, n. pag). All these considerations involve what we see, whether it is improving the quality of the original negative, restoring elements of the narrative, or re-tinting the film. There were also two prior restorations of the film - in 1976 and 2007 - that were completed by the SFI, which were "used as a reference for some scenes in the film" (n. pag), according to Mair. For the 2007 project, they made the print "from the original camera negative, recreating the tinting and toning as well as the intertitles,

which had been lost” (Horak, n. pag). As intertitles are invaluable for delivering dialogue and narration, the preservation of story details is in the hands of the individuals who restore the film. 
From a musical perspective, some emphasize experimentation and personal touch alongside fidelity. While this is partially due to the scarcity of existing materials, original scoring has become common at silent film exhibitions in repertory theatres. For instance, the Mayfair Theatre in Ottawa, Canada, hosted a screening of Häxan in 2019 with live musical accompaniment by the VOC Silent Film Harmonic. Their methods evoke "how many silent films were originally presented - taking themes and using them as the basis for inspiration" (n. pag), respecting original intention while also permitting creative interpretation. Although this allows for more inventiveness from the contemporary composer, this language echoes Högberg and Rundqvist's faithfulness to Häxan's original presentation.

\section{'A Cultural and Historical Presentation': The Narrative of Häxan}

The narrative structure of Häxan incorporates seven different "parts." This is likely due to the one-projector system in theatres at the time; as the reel was being changed, there would be a pause in the action, and this structure ensured that audiences would not be confused. Films with several parts were also often long, and showed off their production value, enhancing their prestige by framing the moviegoing experience as an event. Although the lecture at the beginning appears to stand on its own, as does the last part - to a lesser degree - it is probable that this arrangement was due to practical and promotional considerations, as opposed to a concerted narrative or stylistic strategy.

Häxan could be considered as a predecessor to the mondo film, whose "images [are] understood as catalogues of nervous disorders and psychotic symptoms" (Brottman, 168), and unafraid to show "the violation of the human body" (168) in an exceptionally realistic fashion. As the film begins with a lecture, which instructs the viewer on historical attitudes towards the Devil and witches, this didactic tone sets the stage for later instruction - both visual and written - on torture. More broadly, this positions Häxan in the docudrama tradition, which mixes the fictional qualities of dramatic narrative with the ostensible connection to reality inherent to the documentary. However, as with documentaries since their beginnings, there is a clear narratorial presence in Christensen, who literally appears in 
close-up and even explicitly mentions his control over the theater programme. This opening lecture also incorporates a series of drawings and sets both made for the film and from various academic sources, cited within the intertitles. An offscreen narrator also uses a lecture stick to highlight certain features in the illustrations, and irises often facilitate the formal transition from slide to slide, evincing an academic interest in these beliefs. The narrator also uses "I" throughout the film, using a first-person perspective that personalizes the presentation of the narrative.

The second part depicts a young woman's attempts to purchase stronger and stronger love potions to woo a "pious monk" from a pair of witches. One witch, Karna, uses ingredients like cat feces, dove hearts, and boiled male sparrows to achieve these effects, which are eventually successful. There is a consistent tension between the church and witchcraft here, but also between the church and scientific curiosity. For instance, two men retrieve a corpse for dissection in the name of curing diseases and pray for forgiveness beforehand. Another young woman witnesses this event and runs to inform others of this "witchcraft." Elsewhere, the Devil harasses a group of monks studying holy texts, lures women out of their marriage beds and into the forest, and attacks those who fall for his tricks. He also lures Apelone, Karna's companion, into a castle in the sky, where he taunts her with lavish accommodations and riches. Partially achieved through double exposure and stop-motion animation, these sequences do not argue for the Devil's actual existence, but rather accentuate the real fear that medieval persons had toward him, which ironically sustained his powers.

The third part depicts a fictional episode of inquisitors investigating evidence of witchcraft. Suspicion over her husband's illness leads a woman, Anna, to surmise that a hungry weaver, Maria, is a witch. Terrified over conjectural details, like Maria's ravenous appetite and concealed features, Anna runs to the Pope's inquisitors with her concerns. Although a senior inquisitor warns Anna against false accusations, this light warning does not prevent Maria from being imprisoned. The fourth part continues this story, as they attempt to physically and psychologically coerce a confession out of her. 
These forced admissions precipitate a horrific scene of Satanic celebration in the forest, where the Devil cooks a meal of unchristened children, and "witches" affirm their loyalty to him. These events do not occur within the diegesis; they are representations of Maria's breathless fictions, coupled with the paranoid imaginations of her prosecutors.

The fifth part further highlights the hypocritical and insidious procedure involved in identifying someone as a witch. Maria subsequently accuses Anna of witchcraft, who is imprisoned and herself coerced into a confession. A monk asks her to teach him how to create thunder through water; in return, he will let her go free. Tears allegedly indicate one's innocence, but as Anna cries, a senior monk admonishes his skeptical subordinate, arguing that it is merely spittle that she smeared onto her face. She eventually confesses, with one monk excitedly leaping at the coerced confession and the other leering in triumph. As the inquisitors move on to another town, the film shows that this is not a unique occurrence, but rather a common practice that powerful institutions can repeat through fear and authority.

The sixth and seventh parts involve several fictional episodes, including an overview of $20^{\text {th }}$ century medical cases. By juxtaposing these two segments, Christensen argues that our perception of unusual modes of behaviour has drastically shifted over the centuries. However, as he makes clear at the very end of the film, the treatment of the elderly and the infirm in the $20^{\text {th }}$ century is still far from ideal, as we effectively marginalize them in society. One of his last case studies involves a nun named Cecilia, who succumbs to the Devil's possession and gets shunned by her fellow sisters. In contrast to other horror films we have looked at, the Devil is always influencing others; he is not a creature that you can destroy, banish, or control. He transcends time and space, and those who may have undiagnosed conditions are the ones that society punishes. In the seventh part, through a series of closeups and re-enactments, we are shown how various physical qualities - such as nervous disorders and somnambulism - would have been construed as marks of the Devil in medieval times. Along with the 
fictional scenes of the Sabbath and the Devil's activities, this narrative structure represents the inventions of the paranoid alongside an incisive investigation of medical parallels. As "The film engaged closely with the Malleus [Maleficarum] and consciously reflected several of its beliefs whilst carefully critiquing them" (Nash, 394), this also reflects the adaptive context of the film.

The last section of the last part also deals with a contemporary story that highlights the theme of superstition, especially with regards to medical diagnoses. Although the narrator says that the witch's insanity can be explained by nervous exhaustion, they also mention that the Devil does not belong solely in the past - meaning these assumptions also exist in the present. The gender and sexual politics of these "modern" diagnoses are also apparent, given Christensen's casting of the same woman to play the variety of afflicted patients, as if equalizing their struggles and assuming an ideal example. The idea of the hysterical woman, whether disposed to strike matches or steal objects, is also a problematic one, which seems to borrow its premises on psychological disorders from the era it purports to improve on. This also extends to institutions; as the narrator says, "Poor little hysterical witch! In the Middle Ages you were in conflict with the church. Now it is with the law." This shift from religious to secular law enforcement, in many ways, has done nothing to abate the stigma associated with these conditions.

This can also be associated with cultural trauma. The kleptomaniac character, pleading with the shop owner who caught her stealing, mentions that "I have been tormented by a persistent fear during the war. I am a broken person." Connecting her mental illness to the strain of living under the threat of occupation or annihilation, she hints at the broader anxieties that European countries were gripped by during World War I. "It is as if an unknown power compels me," she says, like a powerful evil has been given influence through the pervasive fear of the time period. She also mentions that her husband died in the war and she has not been the same since, making these national wounds personal. As a result, we are left to wonder what personal or cultural traumas might have contributed to nervous disorders that may have been construed as evidence of witchcraft during the medieval era. One thing 
Christensen seems to highlight, at the very least, is that we are slightly more predisposed to listen - the shop owner promises not to pursue the matter if she never visits the shop again. This association of criminal behaviour with cultural trauma positions Häxan as an example of shellshock cinema, which we have previously connected with Expressionist cinema and the writing of Anton Kaes. What makes Haxan's example unique is its focus on the suffering of women; while this is undoubtedly sensationalized, as the thumbscrew segment demonstrates, the harrowing effects of anxiety - brought on by the war - are treated quite seriously, as is the patriarchal oppression of women throughout.

\section{'A Nightmare, A Raging Demon, A Seducer': The Devil in Häxan}

Christensen explicitly associates the presence of the Devil (played by Christensen) with the credulity of the populace in question. Right before his first appearance, the intertitles read "people's belief in [the Devil] was so strong during the Middle Ages that he became real," as if they paradoxically conjured him out of nothing through their faith in his existence. We then see a monk studying a holy text in a medium shot, with his back turned to us, facing a pitch-black background at an altar. As if he is practicing his religion at the abyss of Hell, tempting its forces with his beliefs, the Devil leaps out from nowhere and lays his claws on the altar, staring the monk down. Christensen depicts - and portrays - him as a humanoid figure with scaly skin, two short horns, and two longer horns, his facial features obscured by shadows. We see an extreme close-up of the monk, his face wideeyed in terror, perhaps standing in for the ideal spectator. He flees into the abbey, motioning furiously to his colleagues in the Devil's direction, and presumably escapes his clutches - as he does not pursue the monk. As with several shots in the film, including the cover of the Criterion Blu-ray - which features a naked woman, from behind, facing the Devil - this has grotesque connotations. Specifically, it suggests oral sex, while other images have equally carnal overtones; for example, the churning of the Sabbath meal indicates masturbation, or pleasure outside the marriage bed. These compositions connect the gory with the erotic, which are usually depicted separately to either repulse or stimulate the viewer. 
When placed together, they unsettle the viewer; in a faith-based context, these scenes frame the Devil as blaspheming religious rites by simulating forbidden sexual activities alongside gruesome imagery.

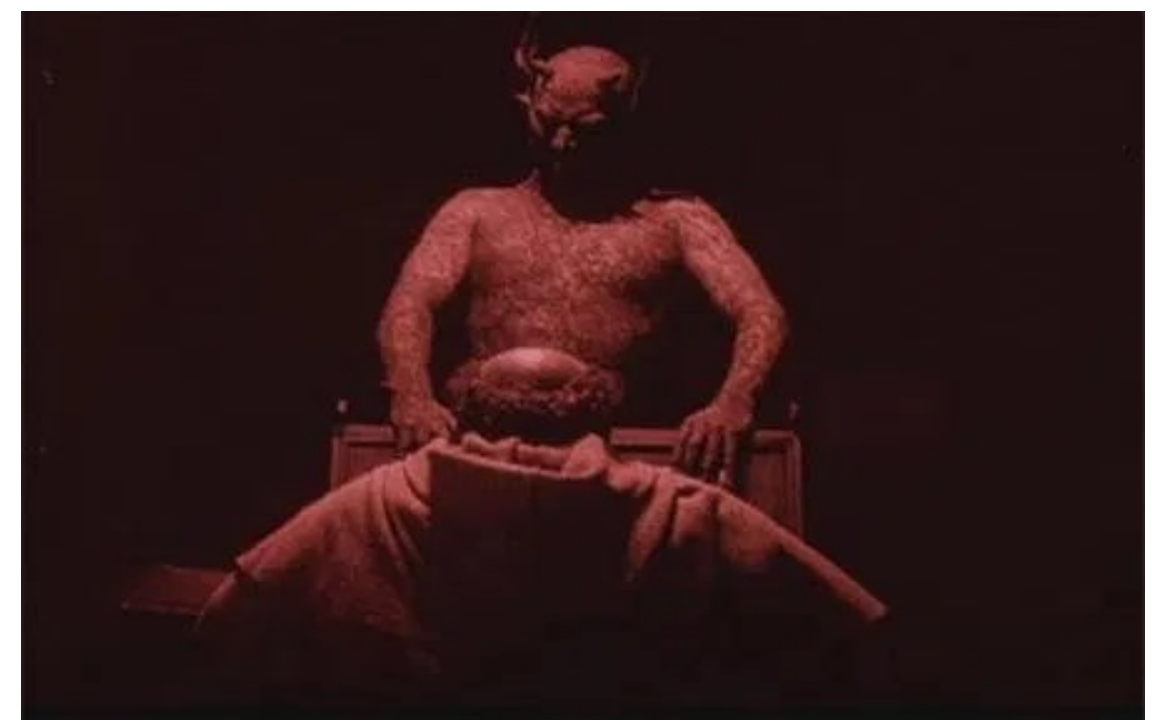

More intertitles inform us that "The devil is everywhere and takes on all shapes. He shows himself as a nightmare, a raging demon, a seducer, a lover, and a knight." Firstly, this establishes his ubiquity; the Devil may appear embodied, but he is ever-present, just as God is. Moreover, the Devil “taking on all shapes” is reminiscent of Noël Carroll's categorization of certain monsters as “categorically interstitial" (32), which "cross the boundaries of the deep categories of a culture's conceptual scheme" (31) and are "impure" (31). Again, Christensen subverts this characterization by primarily depicting the Devil as a singular entity, with witches and demons as subordinate monsters. Carroll's "impurity requirement" (47) is insufficient here, which he defines as linking "distinct and/or opposed categories by fission or fusion” (47), as with Pazuzu possessing Regan MacNeil (Linda Blair) in The Exorcist (William Friedkin, 1973). In Häxan, the Devil threatens monks and attacks women after seducing them, using sexuality and blasphemy as instruments of violence. Although he appears as human, his "impurity" comes from his curved horns and his long claws, the latter of which are occasionally highlighted on their own - Christensen has the Devil poke a naked woman to demonstrate that these areas subsequently feel no sensation when examined by inquisitors. His body is also not 
dissimilar to the fat monk's, possibly serving as a reflection of the monk's darkest impulses. The abyss could be a mirror into the monk's soul, which would recall Dr. Frankenstein seeing the Monster in the study's mirror. As a result, we can read the intertitles as a lecture piece on the Devil as commonly understood in our culture, rather than a character analysis of Christensen's portrayal.

Ironically, Carroll also refers to a trope in horror fiction called "Sympathy for the devil," which involves "the audience's moral evaluation of the monster [when it shifts] in the monster's favor" (143). In Mary Shelley's Frankenstein, the monster is not born evil, and he can clearly articulate his moral quandaries. However, in Edison's adaptation of the novel, the monster is created from Frankenstein's worst impulses and is unequivocally condemned. In The Golem: How He Came into the World, Rabbi Loew creates the Golem to protect the Jewish people from persecution, but the demon Astaroth corrupts these good intentions. On the other hand, in almost all his many incarnations, the Devil is wholly evil, with no redeeming qualities or ethical ambiguity. We do not feel pity for him, nor are we supposed to empathize with his motivations. The intertitles serve as a warning, and his representation serves as a threat; the Devil comes in many forms, and if you fall for his tricks, you will pay the price.

Shortly after, the Devil opens the window of a young couple's bedroom, again obscured by shadow, looking for his next victim. After knocking on the shutter door, startling the woman awake, he beckons her to come with him. Taking one last glance at her sleeping lover, she falls back into bed peacefully - then turns around and falls into the Devil's arms. He also creeps slowly across bodies in bed, strangles someone against a smoky backdrop, and lures a naked woman - hands outstretched into a garden, where she bows to a demon. Here, Christensen depicts the Devil as a wicked seducer, intruding in the family home and blaspheming the sanctity of monogamous unions. Most importantly, "the normality of belief in witchcraft and in the devil is emphasized" (Sharpe, 85), instead of being characterized as a delusion. Of course, this persists in some belief systems, which challenges the assumption we do not believe in the monsters of horror cinema. Although the spectator and the 
characters both recognize the monster's horrifying qualities, "unlike the characters, we do not believe in its existence" (18), according to Carroll. He also compares the Devil to other "figures of medieval superstition" (169), such as the incubus, vampire, werewolf, and witch. Although we are treating him as a fictional character, to categorize him with mythological figures and Universal Monsters does not do justice to the enormous impact he has had on world cultures since their beginnings.

Perhaps the most bizarre - and gruesome - sequence in the film involves the witches' Sabbath, which the Devil and his grandmother attend, to whom a group of demons feeds a dinner of toads and children. In a bacchanalian scene filled with wild revelry, gruesome creatures, and occult materials, the grandmother lectures a witch about the ritual. In a close-up of these features, including a skull and bones, an hourglass, and candlesticks, she points to them using a stick, as if emulating the lecturer from the beginning. Richard Baxstrom and Todd Meyers argue that "this is almost certainly a reference to Circe...her transformation of men into hybrid animal creatures was...cited as evidence of the timeless, universal nature of the evil of witchcraft" (117). Although this mythological reading may be accurate, it also reflects - and perhaps satirizes - the role of the lecturer in early cinema, and in schools as well.

This is also true of early visual culture in general. Lecturers with slide shows were popular long after the silent period and were very important in the late $19^{\text {th }}$ and early $20^{\text {th }}$-centuries. Also, religious slides would be popular in many churches as well as secular halls. In a way, Christensen's treatment of this could be a parody of this role; as he demonstrates later in the film, his treatment of the material is not without a dark sense of humour. However, there is a genuine interest in directing the audience's attention to certain details in the paintings and dioramas, accompanied by intertitle narration that is not sarcastic or flippant. As Rick Altman observes, "The first twenty years of cinema history are...heavily marked by successive waves of lecturers" (55), so this role would have likely been familiar to many silent film audiences. Amidst the bloody sacrifices and Hadean atmosphere, this lesson serves the same 
function, which is to establish context for what the spectator is witnessing. The significance of this role relative to Häxan's generic designation will be explored further in the following section.

\section{Didactic Horror: The Problem of Genre in Häxan}

As with Frankenstein and The Golem, and most other silent films, performers would play music at theatres screening Häxan. An original score accompanied the film's release, which other composers have since staged or re-interpreted. They have also made their original compositions to accompany new prints of the film, as with Matti Bye's scoring of the Swedish Film Institute's version. As for its designation as a horror film, the situation is more complicated. The audience should fear the Devil and his minions because of the gruesome makeup, menacing performances, and intertitle narrations. Christensen also frames the excessive credulity of medieval monks as contributing to the Devil's existence and argues that they mischaracterized the behaviour of mentally ill persons as evidence of witchcraft. In some way, these approaches play on the audience's fears, fulfilling the affective mandate of horror beyond the monstrous figures they include. However, it also contains documentary elements, especially towards the beginning of the film. The lecturer shows us classical impressions of Hell and celestial bodies, which were prevalent at the time of the fictional episodes. Here, Christensen establishes how people were capable of advanced knowledge while also engaging in primitive fears and suspicions.

The film opens by calling itself "A cultural and historical presentation in moving pictures in seven parts." Instead of foregrounding its fictional elements, it uses adjectives that evoke a prestigious, even academic quality to what it shows. Christensen reinforces this by mentioning that his "main sources are mentioned in the theater's program," taking care to draw the audience's attention to a builtin bibliography of sorts. A quick close-up of Benjamin Christensen's intense stare follows this introduction, and intertitles inform us that he "wrote and produced the film between the years 1919 and 1921." Christensen then gives personal thanks for the cinematographer (Johan Ankerstjerne) and art 
director (Richard Louw). While credits are commonplace in films, this is an unusually intimate gesture on the part of the filmmaker. Finally, he invites the audience to "look into the history of mysticism and the mysterious chapter known as the Witch," drawing attention to its esoteric qualities and the attraction of the unknown.

As a chapter in the "history of mysticism," we can associate Häxan with a broader interest in these occult beliefs that extends across silent horror cinema. For instance, in advertising materials for Edison's Frankenstein, the producers wanted to emphasize the "mystical and psychological" elements of the novel, rather than situations that would horrify audiences. In The Golem: How He Came into the World, the mythology surrounding the titular monster stems from a mystical sect of Judaism called Kabbalah. While it is not explicitly associated with horror - even removed, as with Frankensteinmysticism is connected to magical practice, whether benevolent or malevolent. Häxan neatly fits into the latter category; while it denounces witch-hunt hysteria as a crude reaction to mental illness, it still features sequences depicting the exploits of witches and the Devil. One accused witch imagines a crowd of witches flying over a townscape on their brooms, which the film achieves through a stunning use of superimposition, along with "a series of swift tracking shots of stationary actors" (Baxstrom and Meyers, 115). Through these scenes and representations, the film contributes to the same history it interrogates, associating mysticism with black magic as a result.

Through a series of irises and fades, Christensen shows a series of wood carvings and paintings, which depict witches brewing potions, fantastical creatures, and renderings of Hell. As the film presents us with these artworks, which all originate from a fear of witchcraft, it also gives us its central thesis: "When primitive man is confronted with something incomprehensible, the explanation is always sorcery and evil spirits." Earlier intertitles highlight this by arguing that "The belief in sorcery and witchcraft is probably as old as mankind itself." Rather than saying "primitive man is confronted by witches," or "Witches are as old as mankind itself," the film foregrounds the rationale necessary to 
sustain these archaic belief systems. It is not that witches and the Devil exist, but that fear motivates certain people to believe that this is the case, resulting in actual atrocities. Modern audiences convince themselves that there is a comfortable distance between them and this irrationality; as James Sharpe argues, "it is easy...to see the belief in witchcraft as something evil and stupid which progress has allowed us to leave behind" (84). However, if we interpret the real objects of our fear to be hysteria and persecution, and not monsters like witches and the Devil, the film does take on a disturbing relevance. While Häxan is mostly set in medieval times, and deals directly with superstitions within that context, it argues that this irrational behaviour carries into the present (of the film), perpetuating myths about mental illness that sustain the bad treatment of its patients. While this is not the same as the murderous hysteria of the religious inquisitors, their ridiculous "diagnostic" tools for witchcraft are undergirded by the same superstitious fervour as those who ruthlessly marginalize the mentally ill and traumatized. Again, as with the kleptomania case, her hysteria apparently comes from a traumatic shock of grief and lack of sexual life. Christensen problematizes this definition of mental illness here, as experiencing trauma does not necessarily mean one is suffering from a condition. By concluding with a scene in which a woman steps into a cold shower, and juxtaposing it with a shot of witches burning at the stake, he is arguing that strategies of dealing these cases share more similarities that people would care to admit, as they still ostracize those who exhibit symptoms or certain types of behaviour.

The didacticism of the lecture anticipates later forms of documentary, including those that incorporated an authoritative voice to explain complicated concepts to the audience. In this mode, this voice - quite literally - spoke on the subject matter of the film, shaping reality through the image as well as the dialogue of the lecturer. The approach of this sequence is quite similar; as the drawings and woodcarvings appear onscreen, intertitles follow that describe the scene. Occasionally, a pointer juts into the frame and highlights a detail, emulating a university class as well as the classical role of the film lecturer. The irises and fades are a stylistic reflection of this academic context as if the professor - 
or "authoritative voice" - is going from slide to slide while they are elaborating on the subject matter. Some scholars have challenged Häxan's cinematic nature as a result of this. For Baxstrom and Meyers, "a filmed lecture would not generally qualify as a satisfying film-going experience for anyone but the most dogmatic viewer. Continuing in this way may not even qualify Häxan as a work of cinema" (84). More than anything, they seem to be frustrated by the lecture style of this segment, which is more of a tonal critique, rather than a convincing argument about its inherent essence as a film. We can also return to Häxan's categorization as a "mondo" film here, which "tells the story of broken taboos, or chaos and disequilibrium" (Brottman, 168), and "provides a fierce critique of the traditional horror film" (168). The footage of some mondo films is also "held together by a loose documentary-style commentary, but is more often left to speak for itself" (168); this could certainly be applied to Christensen's lectures, which do not dominate, but roughly bookend the film's fictional sequences.

This documentary section at the beginning also references specific scholars, including George Rawlinson and Gaston Maspero, furthering the bibliographic attention to detail that Christensen wants. While he shows drawings directly from their texts, Christensen also includes representations of celestial bodies original to the film, including stars hanging from ropes and artificial mountains underneath. The idea that "celestial bodies...influenced our characters, behaviors, and fortunes" (Browne and Porot, n. pag.) is heavily deterministic, but it also has mystical connotations, which the opening intertitles contextualize. Although the depiction of witches and devils is frightening, as is the behaviour of people that would persecute mentally ill people, there is a broader concern with mystical planes of existence. As the intertitles note alongside the stars and mountains, "According to the beliefs of other ancient civilizations, the sky was vaulted, and the earth shaped into terraces." While these instructive elements may seem strange to include in a horror film, especially the cosmic themes, they are relevant to its thesis. "When primitive man is confronted with something incomprehensible," they offer explanations that subsequent generations may refute or decry, depending on the context. 
Mysticism, the cosmos, witchcraft, and monsters are all connected by the belief systems that facilitate their relevance in the first place.

\section{'The Little Woman, Whom We Call Hysterical': Witchcraft and Mental Illness in Häxan}

While the film certainly includes scenes that depict horrific acts of violence, including the Devil dropping a dead baby into a cauldron for a meal, it does offer a complicated examination of mental illness that the Malleus Maleficarum does not. The book provides instructions for identifying and killing witches, wholly vilifying those that others wantonly accuse of the practice. On the other hand, despite indulging in sequences suited to the horror genre, Häxan "[investigates] the possibility that mental illness could be behind events that lead to witch-hunting hysteria" (Paciorek, 276). This interest in the psychological underpinnings of behaviour that others construed as witcheraft goes beyond the depiction of a "monster" as evil. There is no virtuous savior that must destroy the witches to restore order. Instead, they lack the understanding necessary to view them as suffering from a condition.

The monks employ ridiculous litmus tests for the identity of witches, such as the ability to cry on command "in the name of the Holy Trinity." However, many talented actors can accomplish this, further undermining their logic. They also manipulate them emotionally, promising freedom in exchange for demonstrations of magic, and using their children as leverage. They describe the condemned woman's punishment of burning as "edification for man, as a sweet scent for God," as if there is an educational element to such violence, which God ordains as just. Although we often use "man" as a catch-all term for humanity, one cannot help but note its gendered connotations here especially in this scene. Christensen also notes that "over 8 million men, women, and children were burned as witches," providing a broader overview of the statistics during those centuries. As the monks file out of the courtyard with the captive witch, the long shot showing a hollow emptiness after the chaos of the judgment, the intertitles note that "There are witch confessions that are completely insane," underlining the coercion involved in such trials and investigations. 
Social scientist Jack Fritscher and high priest Anton Szandor La Vey argue that Christensen "sensationalizes the sex and sadism of a repressive Christianity on its circumstantially trapped victims" (104), through the erotic and violent sequences that depict the content of their confessions. They also observe that "Long passages dwell on the salacious torture of helpless women" (104); in the seventh section, there are also plenty of close-ups of the instruments that inquisitors used to inflict this abuse. As anonymous assistants hold them for the camera, as if they are artifacts in a lecture, the larger devices are shown with live bodies attached to them, giving this fascination a corporal dimension. One self-reflexive sequence sees Christensen test the thumbscrew on an actress who allegedly requests it, thinking it will not be as painful as all that. Intertitles say that "I will not reveal the terrible confessions I forced from the young lady in less than a minute"; although she appears to be smiling throughout, intermittently wincing in pain, this short scene lends credence to the argument that Christensen makes a spectacle out of the suffering of women.

\section{Conclusions}

Häxan is the most culturally pervasive silent horror film to come out of Scandinavia. A Swedish production with lots of Danish creative personnel, it has "entranced, entertained, shocked, and puzzled audiences for nearly a century" (Doty and Ingham, 1). Banned in the United States for its sexual content and graphic violence, it quickly acquired an international reputation for its gruesome depictions of Hell and witches' Sabbaths. Its director, Benjamin Christensen, eventually moved to the States to continue making horror films, but they ended up being far more pedestrian and studio-driven then his earlier creative efforts. His multifaceted examination of witchcraft and false persecution remains his most enthralling work to date.

As with many silent horror films, several cultural organizations have restored and preserved Häxan in different formats. From these, we learn about the use of the original camera negatives, and the importance of fidelity to the filmmaker's intent when making alterations or updates. These involve 
tinting and toning, which renovate the color palettes of the image for the new edition. For instance, the deep reds evoke the Devil's pervasive influence, and the eerie blues accompany nighttime scenes in villages and forests. Both Blach's and the SFI's respective efforts highlight the silent film text's potential as a palimpsest, as well as the impulse to respect the filmmaker's original aesthetic.

Häxan's narrative structure incorporates a lecture-style introduction, followed by six fictional episodes that interpolate documentary elements. In this way, Christensen effectively illustrates his thesis: that medieval belief in witchcraft and the Devil gave them the power that they would have had, were they real. This is echoed by Richard Baxstrom and Todd Meyers, who argue that "Christensen intended to make a case for witchcraft as misidentified nervous disease and to highlight the incompatibility of superstition and religious fanaticism with modernity and science" (2). By educating the audience about the worldviews of ancient civilizations, the film provides crucial context for the rest of the stories while also establishing an academic approach to its subject matter. When we see sensational material, like the gory scenes of Sabbath celebrations, we then recognize them as imaginings motivated by feverish paranoia, stoked by the ideologies of the time. The last few sections, which depict the unjust procedures used to identify and persecute "witches," show the real monsters to be the inquisitors. They go from town to town, manipulating predominantly older women to confess under duress to achieve their ostensible quota. As the last episode makes clear, medieval persons may have also interpreted undiagnosed physical and mental disorders as evidence of possession. The film searches for rational explanations to the fantastical and horrific elements it represents as fiction, which completes its scientific approach to its subject matter.

In terms of representing classical "monsters" in silent horror cinema, the Devil is the most obvious example in Häxan. While the film encourages the spectator to see the Devil as an invention, the style of his depiction is still worthy of note. Christensen portrays him as a muscular, slightly animal man, with curved horns and a wiggling tongue. While he strangles people twice, he mostly influences 
others to evil or indiscretion; he coaxes women out of their marriage beds, interrupts study sessions of holy texts, and makes pacts in return for services. In contrast to Frankenstein's monster and the Golem, whom supposedly educated men created for a specific purpose, the Devil is a primordial force of evil defeated only through incredulity. Although intertitles relate that he takes on many forms, satisfying Noël Carroll's “impurity" requirement for monsters, he appears in the film as more human than interstitial.

Häxan also defies genre unconventionally for silent horror cinema. Its use of documentary elements, including its lectures on primordial entities and celestial bodies, and fictional episodes are not entirely separate. In the first section, the spectator is watching someone study documents and representations of subject matter that is pertinent to the film. Later scenes blend inquisitorial drama with Satanic horror; as we empathize with the unjust persecution of medieval women, the creatures and ritualistic practices horrify us. On the other hand, we also fear the belief systems that lead to this treatment, as these beliefs fuel the pervasive paranoia surrounding possession and witchcraft. This is not mutually exclusive of the inquisitors' apparent enjoyment of inflicting pain on the helpless, like the smiling monk who manipulates Anna. Through a complex intersection of narrative structure, performance, and subject matter, we can associate our affective engagement with Häxan to its genre. Christensen educates us on the nature of fear and depicts its different manifestations - whether fantastical and imaginary or all too real.

The ideal spectator is seemingly disgusted and terrified at the events and personalities depicted in the film. From the iconography of the witches' Sabbath, including the different creatures, to the graphic violence that occurs, it is hard to imagine another appropriate generic label. But just as we must question the designation of "silent cinema," given the extensive research into musical accompaniment, we must also interrogate easy generic categorization. 


\section{Conclusion}

It is difficult to choose three ideal case studies from a period in film history that has lost so much to time. This is especially true of the period between 1896 and 1910, when filmmakers were exploring the many possibilities of a new medium. It is even more challenging to pick from different countries. Japan, for instance, produced two of the earliest films with horror elements as well: Shinin no sosei, and Bake Jizo (both w. Eijiro Hatta, 1898). These films come with their own national contexts, but they also share similarities with films we have explored. Film historian Hiroshi Komatsu characterizes these works as "skit films exploiting trick effects" (177), like Le manoir du diable, but he mentions that these cinematographers honed their skills by filming cultural performances, such as geisha dances. While it is still hard to pick, there is evidence of similar content and style across the world, with each country's cinema likely importing something from popular artistic traditions.

Early films, especially horror films, also borrowed elements from other sources, including stage magic, spirit photography, and optical toys. This is the basis of Murray Leeder's The Modern Supernatural and the Beginnings of Cinema, in which Leeder argues that "where its links with the supernatural are concerned, early cinema's place on a lineage of haunted and haunting media is at least as important as its newness" (3). This can refer to the appearing and disappearing attractions of the trick films, but also to any film that addresses the supernatural, and even cinema as a medium. Perhaps Le manoir du diable chose to include vampires because they were said to turn into bats, which serves as an attractive visual trick. Leeder also mentions that there is a continuing fascination with skeletons, relating to the imagery of the "danse macabre," which is present in Le manoir and persists through Frankenstein. In the latter, Frankenstein has a collection of skulls in his laboratory, which adds to the macabre tone of both his environment and his experiments. At the door of the experiment room is another skeleton, which appears only to serve a decorative function. While it is a cliché that many doctors have skeletons in their offices, this use - like some of Méliès's films - seem to associate it 
more with death, the occult, and the monstrous over life and the medical sciences.

Frankenstein was released on March $18^{\text {th }}, 1910$ when narrative films were first being developed, running around 13 minutes. It was produced in the United States by Edison Studios, whose founder and namesake - Thomas Edison - was an early pioneer of film production and technology. Edison is responsible for several important publicity materials that still exist today, including issues of the Edison Kinetogram, as well as musical cue sheets for accompanying orchestras. The publicity materials tell us that the film focuses "its endeavours upon the mystical and psychological problems that are to be found in this weird tale" (3), over any "repulsive" situations. This wording may also have been influenced by Edison's effort to frame European films as decadent, in contrast to American films as wholesome, as "moving pictures increasingly became inscribed within the rhetoric of moral reform or uplift" (Abel, 101). The cue sheets help us understand the intended dramatic function of each scene by explaining the ideal mood and tempo the music is supposed to elicit. Both demonstrate the early role that company influence played in film exhibition, including anticipating audience reaction to the content in their films, as well as the control these organizations had over certain creative fields including musical accompaniment.

The film was adapted from Mary Shelley's novel of the same name, which - as Edison's concerns might indicate - had questionable content. The film's director, J. Searle Dawley, was also used to helming adaptations, including 1916's Snow White. The disturbing material involved violent actions, including murder, as well as a deeper concern with the power of creation - which was blasphemous to some. While adaptations were common then, given audiences' familiarity with fairy tales, novels, and stage plays, the nature of Frankenstein's story raised new questions about the need to omit or change material. This is likely not the first instance of this happening, but it is a high-profile case, given the level of extant material corroborating it - including several issues of the film journal Moving Picture World. This is inextricably tied to mysticism, which the film overtly substitutes for 
horrific material. This can be seen with Frankenstein's laboratory paraphernalia, including skulls, a skeleton, and candlesticks, which evokes the occult instead of a modern scientific experiment. Creating the Monster from an alchemic concoction, instead of the power of electricity, further highlights this relationship. This curious blend of the modern and the medieval may also relate to the tension in Frankenstein's mind from the start of the film, between his better nature and the evil that compels him to create life.

The Golem: How He Came into the World arrives 10 years later, on October 29 ${ }^{\text {th }}, 1920$, in Germany during the years of the Weimar Republic. In a way, it can be compared to the Frankenstein story, in that a learned man brings a being to life, with the process being corrupted somehow - with the evil in Frankenstein's mind, and the demon Astaroth in The Golem. Although the latter is apparently based on Gustav Meyrink's novel of the same name, it shares more with traditional Kabbalist mythology, including the central role of Rabbi Loew. Although Meyrink's novel and the film are both set in Prague, it is likely that the latter capitalized on the name recognition of the former. For instance, the two previous films are also allegedly related to Meyrink's novel, despite only sharing several small details and telling wildly different stories. It is also possible that the Golem's traditional origin in Jewish folklore, despite being a saviour figure, was convenient from a storytelling perspective. Instead of being a surreal presence that spurred the inhabitants of Prague to evil, as in the novel, the Golem's original story provides the narrative basis of being created by a wise man, corrupted by an evil entity, pushed to violence, and defeated in the end, as with any kind of monster. Given the novel's emphasis on the multifaceted ugliness of its setting, it is curious that that did not inspire the nascent Expressionist impulses of the time, given its focus on environment and character psychology.

Given the esoteric nature of Kabbalah, there is a further interest in mysticism with this film. Like Frankenstein, it is directly tied to the creation of the monster figure. By pressing an amulet into the Golem's chest, along with the word "Aemaet" given to him by Astaroth, Rabbi Loew creates life. 
As with Frankenstein, modernity and antiquity are both present; whether it is through the slightly anachronistic set design, or even the costumes, there is a strange timelessness to the proceedings. In a way, this is what the film borrows most from Meyrink's novel - a sense of space that, despite purporting to be from a specific time period, unsettles you through its depiction of that space-time relation. However, this makes sense given the film's canonization in the history of German Expressionism. As German drama scholar William R. Elwood notes, "the expressionist artist sought to communicate...the dark and timeless world of the unconscious" (103), as opposed to one that strictly corresponds to our reality.

Häxan was released only two years later on September $18^{\text {th }}, 1922$, in Sweden. Unlike Frankenstein and The Golem, it is not clear that its monsters exist in the diegesis. And unlike The Golem, it is not an Expressionist film, but it makes excellent use of its settings relative to character behaviour and is highly expressive and evocative. Witches and demons gather at nighttime in dark forests, engaging in occult rituals and human sacrifices. Human monsters, including the inquisitors and false accusers, imprison innocent women in claustrophobic basement prisons that contrast with the wide-open spaces of convents. This use of space highlights the power that some institutions have, including religious authorities, but it also illustrates the influence that even the idea of Satanic activities holds on their minds. Fears of these large underground gatherings, which constitute a subversive threat to the established order, motivate their attempts to control those they believe to be witches.

Modernity and the occult - or even medieval beliefs - are also in conflict here, as with Frankenstein and The Golem. As Alexander M. Doty and Patricia Clare Ingham note, "Christensen...reinforces the image of [the] Church as a regressive and medieval space, one that stands in distinction to the apparently more progressive architectures of modern science and medicine" (45). Both Frankenstein's laboratory and the site of Rabbi Loew's ritual could be "medieval spaces," which eschew modern science in favour of the occult and magic. Both also connect to religion in different 
ways; making Frankenstein's monster is a blasphemous affront to God, but making the Golem is a protective measure that is sanctioned by God. Even the latter has occult elements to it, as Rabbi Loew consults the stars; Häxan's introductory lecture also focuses on the significance of celestial bodies. This relationship between the old and the new can be extrapolated to the silent cinema in general, as filmmakers continuously experiment with technology, narrative, and style.

Häxan also approaches genres from a unique perspective, using the docudrama format to argue its thesis. By incorporating real-life elements, including the instructional lecture and academic sources, the film supports its depiction of medieval beliefs through existing material and an authoritative voice. This narrator guides us through the film, staying consistent even through what could be considered its fictional episodes. As a result, it is possible that the intertitles - besides dialogue - serve the same function throughout the film, which is to provide information on a subject to the spectator. Whether the narrator is pointing to details on a woodcarving or accompanying the depiction of the Devil and witches, they do not appear to be present in the diegesis. The supernatural scenes in the film do not have to exist on the same plane of reality as the interrogation sequences; it is just convenient for the narrator to show them to get their point across. From a generic perspective, this is complicated; what is documentary and what is drama? Do they interact fluidly? Fluid interaction is likelier and fits more cleanly with Christensen's creative strategies. While the first episode has documentary elements, the last section - detailing modern responses to mental illness - combines both, using fictional scenes under the aegis of documentary truth. Film scholar David Coleman observes that "Häxan...is largely structured as a docudrama, purporting to be a lecture about the true history of witchcraft versus its root causes in persecution of the mentally ill... [while also] given to flights of cinematic surrealism" (59).

All three films, in some way, share a fascination with monsters. Each of their monsters is somehow connected to a mystical tradition, whether it is alchemy, religious rites, or malicious superstition. As we have seen, silent horror films predate horror cinema itself, as the term was not 
applied as often at this point. As a result, these films embraced the esoteric wonder of mysticism before the genre started to manifest in marketing, first with the Universal Monsters series. However, their reasons for doing so are quite different; Frankenstein, for example, did not want to alienate audience members who were concerned the film would feature gruesome scenes. Moreover, the stage adaptations appear to have been more gruesome than the novel itself, which was revised in 1831 to include references to these plays. While the novel narrates scenes of murder, this is done in an epistolary fashion; instead of being described as direct action, we hear about such violent scenes through letters written by different characters. As a result, any concerns about disturbing content likely stemmed from the many stage adaptations, which would of course stage these scenes visually.

In The Golem: How He Came into the World, mysticism is intrinsic to Kabbalah, the source of the original golem myth. Mystical thought and practice also frame medieval attitudes towards the world in Häxan, which is then related to superstition and the psychology that motivates mass hysteria. Their monsters are similar in some ways; Frankenstein's Monster and the Golem are both created and corrupted, whether by the evil mind of their creator or the intervention of a malicious entity. The Devil also manipulates the witches in Häxan, although their unconfirmed existence in the diegesis problematizes this. However, Frankenstein's Monster is the $19^{\text {th }}$-century creation of a novelist, the golem story has been around for centuries, and civilizations have feared the Devil for far longer. As such, they belong on various planes of cultural relevance, although the themes the filmmakers are addressing may be alike. In a way, this demonstrates the timelessness of human curiosity, whether it involves creating life, figuring out the heavens, or vanquishing its monsters. Given their retroactive designation as horror films, however, it is likelier that these stories are predisposed to exploring our fears over our triumphs.

There is no doubt that we will continue hearing about further restorations to silent horror films. Whether it is part of a festival programme, a home media release, or another format entirely, 
institutions everywhere are restoring this crucial part of cinema history. In 2017, the F.W. Murnau Foundation preserved The Golem: How He Came into the World on DCP; in 2018, the Library of Congress restored Frankenstein as a digital file; and in 2019, the Criterion Collection released a new 2K edition of Häxan on Blu-ray. Cultural organizations, government entities, and prestige distribution companies are always conducting this necessary work, due to print deterioration and poor preservation strategies, which are unfortunate consequences of the materiality of the film medium.

Every year, every month, and every day, there are opportunities to unearth new films that may re-shape our understanding of the genre and restore existing ones that we need for research. Far from just being entertainment, they are historical documents, with unique narrative and stylistic elements that depict their preoccupations with monsters and mysticism. This treatment of the arcane, of antiquated belief systems and esoteric magic, also makes it stand apart from other historical periods of horror. Far from simply being defined by its lack of synchronized sound, its portrayal of threatening creatures brought forth by magical or religious practices evinces a fundamental mistrust of these rituals. In Frankenstein and The Golem: How He Came into the World, there is an established order that must be saved through the monster's defeat and neutralizing the evil that created them. In Häxan, Christensen critiques the established order, arguing that ideologies that facilitate this system give rise to monsters in the first place. As a result, these films do not explore these themes in a uniform way, but their fascination with this supernatural - and spiritual - subject matter is a similarly old-world preoccupation through the new-world lens of an emergent medium. They also challenge the name that has been applied to them, evading a convenient or comprehensive descriptor. They are not quite silent, and not quite horror; but in their own unique ways, they explore what we fear, and why we may fear it. 


\section{Works Cited}

Abel, Richard. The Red Rooster Scare: Making Cinema American, 1900-1910. Berkeley and Los Angeles: University of California Press, 1999.

“Alchemy.” Merriam-Webster.com. Merriam-Webster, 2019, https://www.merriamwebster.com/dictionary/alchemy.

Altman, Rick. Silent Film Sound. Chichester and New York: Columbia University Press, 2004.

Augustin, Anna-Carolin. "Horror and Magic in the Silent Golem Movies." Blogerim. Jewish Museum of Berlin, https://www.jmberlin.de/blog-en/2017/01/golem-silent-movies/.

Baer, Elizabeth R. The Golem Redux: From Prague to Post-Holocaust Fiction. Detroit: Wayne State University Press, 2012.

Baxstrom, Richard, and Todd Meyers. Realizing the Witch: Science, Cinema, and the Mastery of the Invisible. New York: Fordham University Press, 2016.

Bleiler, E. F. Introduction. The Golem, by Gustav Meyrink. New York: Dover Publications, Inc., 1976. pp. xvii.

Boese, Carl, and Paul Wegener, dirs. The Golem: How He Came into the World. UFA, 1920.

Brottman, Mikita. "Mondo Horror: Carnivalizing the Taboo.” The Horror Film. Ed. Stephen Prince. New Brunswick and London: Rutgers University Press, 2004. pp. 167-188.

Browne, Jacob, and Christophe Porot. "How to Live Through a Horror Story and Still Find Your Self." American Horror Story and Philosophy: Life is but a Nightmare. Eds. Greene, Richard, and Rachel Robison-Greene. Chicago: Carus Publishing Company, 2018.

Buhler, James, and David Neumeyer. Hearing the Movies: Music and Sound in Film History. Oxford: Oxford University Press, 2015.

Byrd, Alfred D. Kabbalah for Evangelical Christians. Morrisville: Lulu Enterprises, 2006.

Carroll, Noël. The Philosophy of Horror; or, Paradoxes of the Heart. New York and London: 
Routledge, 1990.

Christensen, Benjamin, dir. Häxan. Skandias Filmbyrå, 1922.

Coleman, David. The Bipolar Express: Manic Depression and the Movies. Lanham and Plymouth: Bowman \& Littlefield, 2014.

Cooper, Marilyn. “Golem: A Mutable Monster.” Jewish Word. Moment Magazine, https://momentmag.com/jewish-word-golem/.

Davidowicz, Klaus. “Kabbalistic Elements in Popular Movies.” Bauks, Michaela, Wayne Horowitz, and Armin Lange, eds. Between Text and Text: The Hermeneutics of Intertextuality in Ancient Cultures and Their Afterlife in Medieval and Modern Times. Gottingen: Vandenhoeck \& Ruprecht, 2013. pp. 154-163.

Davidson, Gustav. A Dictionary of Angels: Including the Fallen Angels. New York: The Free Press, 1971.

Dawley, J. Searle, dir. Frankenstein. Edison Manufacturing Company, 1910.

Dixon, Winston Wheeler. A History of Horror. New Brunswick and London: Rutgers University Press, 2010.

Doty, Alexander M., and Patricia Clare Ingham. The Witch and the Hysteric: The Monstrous Medieval in Benjamin Christensen's Häxan. Brooklyn: Puntam Books, 2014.

Eisner, Lotte H. The Haunted Screen: Expressionism in the German Cinema and the Influence of Max Reinhardt. Berkeley and Los Angeles: University of California Press, 2008.

Elwood, William R. "Reinhard Goering's Seeschlacht and the Expressionist Vision." Essays on Twentieth-Century German Drama and Theater: An American Reception 1977-1999. Ed. Hellmut Hal Rennert. New York: Peter Lang Publishing, Inc., 2004. pp. 103-109.

“Film 'Il Golem'." Festival del Cinema Europeo. Cineporto di Lecce, http://www.festivaldelcine maeuropeo.com/en-2019/eventi/film-il-golem/. 
Forcen, Fernando Espi. Monsters, Demons, and Psychopaths: Psychiatry in Horror Film. Boca Raton and London: CRC Press, 2016.

Forry, Steven Earl. Hideous Progenies: Dramatizations of Frankenstein from the Nineteenth Century to the Present. Philadelphia: University of Pennsylvania Press, 1990.

“Frankenstein.” Library of Congress. LoC.gov, 2017. https://www.loc.gov/item/2017600664/.

“Frankenstein (Dramatic).” Edison Kinetogram, March 15, 1910.

"Frankenstein 1910.” Julien Dumoulin - Graphic and video design. Jdumoulin.com. http://www.jdumoulin.com/julien-dumoulin---graphic-and-video-design---frankenstein1910.html.

“Frankenstein 1910.” Université de Genève (CH). UniGe.ch, 2016. https:/www.unige.ch/dife/culture/cineclub/frankenstein/1910.

Freedman, Harry. Kabbalah: Secrecy, Scandal, and the Soul. New York and London: Bloomsbury Continuum, 2019.

Fritscher, Jack, and Anton Szandor La Vey. Popular Witchcraft: Straight from the Witch's Mouth. Madison: The University of Wisconsin Press, 2004.

Gelbin, Cathy S. The Golem Returns: From German Romantic Literature to Global Jewish Culture, 1808-2008. Ann Arbor: The University of Michigan Press, 2011.

“Der Golem.” Lost Films. Deutsche Kinemathek, https://www.lost-films.eu/films/show/id/78.

“Der Golem und die Tänzerin.” Progressive Silent Film List. Silent Era, http://www.silentera.com/PSFL/data/G/GolemUndDieTanzerin1917.html.

“The Golem - How He Came into the World." Kanopy, https://www.kanopy.com/product/golemhow-he-came-world.

“Häxan.” The Criterion Collection, https://www.criterion.com/films/352-h-xan.

Hoffman, Edward, ed. The Kabbalah Reader: A Sourcebook of Visionary Judaism. Boston and 
London: Trumpeter, 2010.

Horak, Laura. "Häxan: Witchcraft Through the Ages.” San Francisco Silent Film Festival, http://www.silentfilm.org/archive/haxan-witchcraft-through-the-ages-1922.

Hutcheon, Linda. A Theory of Adaptation. New York and London: Routledge, 2013.

Idel, Moshe. Kabbalah: New Perspectives. New Haven and London: Yale University Press, 1988.

“In Remembrance: Alois F. Dettlaff, Sr.” FilmBuffOnline.com.

http://www.filmbuffonline.com/InRemembrance/AloisDettlaff.htm

“Jan-Jun 1910.” Moving Picture World. New York: Chalmers Publishing Company, 1910. Archive.org. https://archive.org/details/movinwor06chal.

Kaes, Anton. Shell Shock Cinema: Weimar Culture and the Wounds of War. Princeton and Woodstock: Princeton University Press, 2009.

Komatsu, Hiroshi. "Japan: Before the Great Kanto Earthquake." The Oxford History of World Cinema. Ed. Geoffrey Nowell-Smith. Oxford: Oxford University Press, 1996. pp. 177-182.

Kobbé, Gustav. The New Kobbé's Opera Book. Eds. The Earl of Harewood and Antony Peattie. New York: G.P. Putnam's Sons, 1997.

Kracauer, Siegfried. From Caligari to Hitler: A Psychological History of the German Film. Princeton: Princeton University Press, 2019.

Laird, Karen E. The Art of Adapting Victorian Literature, 1848-1920. Farnham and Burlington: Ashgate Publishing, 2015.

Leeder, Murray. The Modern Supernatural and the Beginnings of Cinema. London: Palgrave Macmillan, 2017.

“Lost Films.” Deutsche Kinemathek, https://www.lost-films.eu/index.

Mair, Christopher. “Om Häxans digitala restaurering.” Svenska Filminstitutet, https://www.filminsti 
tutet.se/sv/nyheter/2016/om-haxans-digitala-restaurering/.

Marks, Martin. "Music and the Silent Film." The Oxford History of World Cinema. Ed. Geoffrey

Nowell-Smith. Oxford: Oxford University Press, 1996. pp. 183-191.

Ménard, Sylvain. Symphonies Fantastiques: Musiques de films fantastiques et de science-fiction.

Rosières-en-Haye: Camion Blanc, 2016.

Meyrink, Gustav. The Golem. Prague and San Francisco: Mudra, 1972.

Miller, Jeffrey. The Structures of Law and Literature: Duty, Justice, and Evil in the Cultural

Imagination. Montreal and Kingston: McGill-Queen’s University Press, 2013.

“Monster." Oxford English Dictionary. Oxford University Press, 2002, https://www.oed.com/viewdic tionaryentry/Entry/121738.

Nash, David. "Witchcraft in Film." The Routledge History of Witchcraft. Ed. Johannes Dillinger. Abingdon and New York: Routledge, 2020. pp. 392-402.

Paciorek, Andy. "Nordic Twilight: Scandinavian Horror.” Folk Horror Revival: Field Studies Second Edition. Eds. Hing, Richard, Grey Malkin, Andy Paciorek, and Katherine Peach. Durham: Wyrd Harvest Press, 2018. pp. 276-280.

Phillips, Kendall R. A Place of Darkness: The Rhetoric of Horror in Early American Cinema. Austin: University of Texas Press, 2018.

Rothwell, Ben. "Introduction to 1948 Edition." The Malleus Maleficarum of Heinrich Kramer and James Sprenger. Ed. Montague Summers. New York: Dover Publications, Inc., 1971. pp. V-X.

Schneider, Steven Jay, ed. 1001 European Films. London: British Film Institute, 2007.

Sharpe, James. "The Cinematic Treatment of Early Modern Witch Trials.” Filming and Performing Renaissance History. Eds. Streete, Adrian, and Mark Thornton Burnett. Basingstoke and New York: Palgrave Macmillan, 2011. pp. 83-98. 
Shelley, Mary. Frankenstein: A Longman Cultural Edition. Ed. Susan J. Wolfson. New York: Pearson Longman, 2007.

Shelley, Mary. The Annotated Frankenstein. Eds. Levao, Ronald L., and Susan J. Wolfson. Cambridge and London: The Belknap Press of Harvard University Press, 2012.

Spector, Scott. Prague Territories: National Conflict and Cultural Innovation in Franz Kafka's Fin de Siècle. Berkeley and Los Angeles: University of California Press, 2000.

Sherwin, Byron L. Kabbalah: An Introduction to Jewish Mysticism. Lanham and Boulder: Rowman \& Littlefield Publishers, Inc., 2006.

Tybjerg, Casper. "Shadow-Souls and Strange Adventures: Horror and the Supernatural in European Silent Film.” The Horror Film. Ed. Stephen Prince. New Brunswick and London: Rutgers University Press, 2004. pp. 15-39.

Usai, Paolo Cherchi. Silent Cinema: A Guide to Study, Research and Curatorship. New York and London: Bloomsbury Publishing, 2019.

"VOC Silent Film Harmonic - About." Facebook, https://www.facebook.com/pg/vocsilentfilm/about/?ref=page_internal.

Young, Elizabeth. Black Frankenstein: The Making of an American Metaphor. New York and London: New York University Press, 2008. 